\title{
Predicting the consequences of nutrient reduction on the eutrophication status of the North Sea
}

Hermann-J. Lenhart ${ }^{\mathrm{a},{ }^{*}}$, David K. Mills ${ }^{\mathrm{b}}$, Hanneke Baretta-Bekker ${ }^{\mathrm{c}}$, Sonja M. van Leeuwen ${ }^{\mathrm{b}}$, Johan van der Molen ${ }^{\mathrm{b}}$, Job W. Baretta ${ }^{\mathrm{d}}$, Meinte Blaas ${ }^{\mathrm{e}}$, Xavier Desmit ${ }^{\mathrm{e}}$, Wilfried Kühn ${ }^{\mathrm{a}}$, Geneviève Lacroix ${ }^{\dagger}$, Hans J. Los ${ }^{\mathrm{e}}$, Alain Ménesguen ${ }^{\mathrm{j}}$, Ramiro Neves ${ }^{\mathrm{h}}$, Roger Proctor', Piet Ruardij, Morten D. Skogen ${ }^{\mathrm{k}}$, Alice Vanhoutte-Brunier $^{\mathrm{g}}$, Monique T. Villars ${ }^{\mathrm{e}}$ and Sarah L. Wakelin

\footnotetext{
a ZMAW, Institut für Meereskunde, Universität Hamburg, Germany

${ }^{\mathrm{b}}$ Centre for Environment, Fisheries and Aquaculture Science (Cefas), Pakefield Road, Lowestoft, NR 33 OHT, Great Britain

${ }^{c}$ RWS - Centre for Water Management, P.O. Box 17, NL-8200 AA Lelystad, The Netherlands

d Noctiluca, Van Polanenpark 212, NL-2241 RX Wassenaar, The Netherlands

e Deltares, P.O. Box 177, NL-2600 MH Delft, The Netherlands

${ }^{f}$ RBINS-MUMM, Gulledelle 100, B-1200 Brussels, Belgium

${ }^{g}$ Département Dynamiques de l'Environnement Côtier, Laboratoire Ecologie Benthique IFREMER/Centre de Brest, B.P. 70, F-29280 Plouzané, France

h Instituto Superior Téchnico Universidade Téchnica de Lisboa, Av. Rovisco Pais, P-1049-001 Lisboa, Portugal

'Proudman Oceanographic Laboratory, 6 Brownlow Street, Liverpool L3 5DA, United Kingdom

${ }^{j}$ Royal Netherlands Institute for Sea Research, P.O. Box 59, NL-1790 AB Den Burg, The Netherlands

${ }^{k}$ Institute of Marine Research, P.O. Box 1870, Nordnes, N-5817 Bergen, Norway
}

\author{
*: Corresponding author : Hermann-J. Lenhart, Tel.: +49 4042838 5743; fax: +49 4042838 7477, email address : \\ hermann.lenhart@zmaw.de
}

\begin{abstract}
:
In this paper the results from a workshop of the OSPAR Intersessional Correspondence Group on Eutrophication Modelling (ICG-EMO) held in Lowestoft in 2007 are presented. The aim of the workshop was to compare the results of a number of North Sea ecosystem models under different reduction scenarios. In order to achieve comparability of model results the participants were requested to use a minimum spin-up time, common boundary conditions which were derived from a widerdomain model, and a set of common forcing data, with special emphasis on a complete coverage of river nutrient loads. Based on the OSPAR requirements river loads were derived, taking into account the reductions already achieved between 1985 and 2002 for each country.

First, for the year 2002, for which the Comprehensive Procedure was applied, the different horizontal distributions of net primary production are compared. Furthermore, the differences in the net primary production between the hindcast run and the 50\% nutrient reduction runs are displayed. In order to compare local results, the hindcast and reduction runs are presented for selected target areas and scored against the Comprehensive Procedure assessment levels for the parameters DIN, DIP and chlorophyll. Finally, the temporal development of the assessment parameter bottom oxygen concentration from several models is compared with data from the Dutch monitoring station Terschelling 135.
\end{abstract}

The conclusion from the workshop was that models are useful to support the application of the OSPAR Comprehensive Procedure. The comparative exercise formulated specifically for the 
workshop required models to be evaluated for pre-defined target areas previously classified as problem areas according to the first application of the Comprehensive Procedure. The responsiveness of the modelled assessment parameters varied between different models but in general the parameter showed a larger response in coastal rather than in offshore waters, which in some cases lead to the goal to achieve a non-problem status. Therefore, the application of the Comprehensive Procedure on model results for parameter assessment opens a new potential in testing eutrophication reduction measures within the North Sea catchment.

As a result of the workshop further work was proposed to confirm and bolster confidence in the results. One general field of difficulty appeared to be the model forcing with SPM data in order to achieve realistic levels of light attenuation. Finally, effects of the prescribed spin-up procedure are compared against a long-term run over many years and consequences on the resulting initial nutrient concentrations are highlighted.

Keywords: Eutrophication; Ecosystem modeling; OSPAR Comprehensive Procedure; Eutrophication assessment; North Sea; River nutrient loads; Reduction scenarios 


\section{Introduction}

Many coastal areas of the North Sea are at risk of eutrophication, a process resulting from an increase of anthropogenic nutrient inputs via rivers and other pathways. These anthropogenic inputs can lead to increased production of biomass (Cadée and Hegeman, 2002) as well as changes in the species composition (Philippart et al., 2000). In addition, the increased sedimentation of dead organic material, due to the increased production, in association with bacterial degradation can result in oxygen depletion near the sea bed (Dethlefsen and von Westernhagen, 1983). Cloern (2001) stated that nutrient enrichment due to anthropogenic activities has been viewed as the main cause of eutrophication in coastal areas.

There are a number of definitions of eutrophication: some are scientific (Nixon, 1995; Tett et al., 2007) and others are regulatory (OSPAR). According to the OSPAR (2003) definition, eutrophication is "the enrichment of water by nutrients causing an accelerated growth of algae and higher forms of plant life to produce an undesirable disturbance of the balance of the organisms present in the water and the water quality of the water concerned". The OSPAR strategy aims to eliminate eutrophication. This includes a formal assessment with respect to all aspects of this definition in order to diagnose anthropogenic eutrophication.

One of the goals of the OSPAR Convention for the protection of the marine environment of the North-East Atlantic is to combat eutrophication problems. In order to mitigate the negative effects of eutrophication, in 1988 the PARCOM recommendation was signed by the contracting parties (member states). The aim of this recommendation was that the inorganic nitrogen and phosphorus inputs into the coastal areas should be reduced by $50 \%$ in relation to the 1985 inputs (see page 134, De Jonge, 2006) for those areas where nutrients cause, or are likely to cause, pollution. Generally this goal was reached for inorganic phosphorus, but the inorganic nitrogen input could not be reduced by similar amounts (Claussen et al., 2009).

In order to assess the current eutrophication status for the OSPAR maritime areas, the socalled "Comprehensive Procedure" (CP) was implemented by the member states. This assessment is based on an agreed set of parameters and measures. To implement the CP water bodies are first delineated based on the location of major catchments and salinity. Water bodies are designated as either estuarine, coastal or offshore. Subsequently, the levels of specific assessment variables indicative of nutrient enrichment (e.g. mean winter concentration of dissolved inorganic nitrogen), accelerated growth (e.g. mean chlorophyll concentration during the growing season) and undesirable disturbance of the ecosystem (e.g. concentration of indicator species) are compared with agreed reference levels. The aim of the Comprehensive Procedure was to provide a classification of the regions within the national maritime areas as either a) problem area (PA), b) potential problem area (PPA) or c) non-problem area (NPA). The final report following the first application of the CP was agreed by the environmental ministers at the North Sea protection conference in Bremen 23-27 June 2003 (OSPAR, 2003). A map showing the classification for the southern North Sea is given in Figure 1.

(Fig. 1: about here) 
In support of the strategy to combat eutrophication OSPAR initiated work to predict the eutrophication status for specific water bodies following reduction of riverine nutrient inputs. This initiative built on prior work using ecosystem models to investigate the effects of reduced riverine nutrient loads on the North Sea ecosystem (Lenhart, 2001, Lacroix et al., 2007; Lancelot et al., 2008; Skogen and Mathisen, 2009). As a result of the OSPAR initiative an ecosystem modelling workshop took place in Den Haag in 1996 (Villars and De Vries, 1998). Generally these model studies showed a high response in the winter nutrient concentration to reduced nutrient inputs that, however did not result in a similar response in the biological parameters, such as chlorophyll or net primary production.

For those water bodies classified as PAs additional measures are recommended to reduce the anthropogenic nutrient load into the national maritime waters. In recognition of the fact that ecosystem models can provide information on the expected eutrophication status in relation to planned measures on nutrient reduction within the catchment area of the North Sea the EUC initiated new work using ecosystem models. The work was promoted by the Intersessional Correspondence Group on Eutrophication Modelling (ICG-EMO) and resulted in a workshop held at Cefas in Lowestoft in 2007. The task of the ICG-EMO was to predict the future eutrophication status of specific areas following riverine nutrient reductions using different ecosystem models. Eutrophication status is determined using the OSPAR eutrophication indicator framework (CP). This workshop followed an earlier one held at the IfM in Hamburg in 2005 (see www.cefas.co.uk/eutmod), but with major changes in the procedure to improve comparability of model results. This paper describes the scientific and policy background to the model application, the models used in the study, the procedures used to setup and run the models, an evaluation of the results and conclusions regarding the future eutrophication status of specific water bodies in the OSPAR region.

\section{Model Overview}

The six ecosystem models used to run the reduction scenarios are first described in terms of their main dynamical features. An overview of the domains of the participating models is presented in Fig. 2 and the general characteristics of the models are listed in Appendix A.

\section{(Fig. 2: $\quad$ about here)}

\subsection{Belgium - MIRO\&CO-3D [BE model]}

The MIRO\&CO-3D (in workshop terms BE) model has been developed by coupling the 3D COHERENS hydrodynamical model described in Lacroix et al. (2004) based on the COHERENS model (Luyten et al., 1999) with the biogeochemical MIRO model (Lancelot et al., 2005) to simulate the transport and dynamics of inorganic and organic nutrients, phyto-, bacterio- and zoo-plankton biomass.

The biogeochemical MIRO model simulates carbon, nitrogen, phosphorus and silicon cycling and includes thirty-two state variables and twenty-eight processes linking them, selected as relevant from knowledge of the structure and functioning of Phaeocystis-dominated ecosystems. The description of the MIRO model structure, state variables, processes and conservation equations is detailed in Lancelot et al. (2005, Appendices available at www.intres.com/journals/suppl/appendix lancelot.pdf).

The MIRO\&CO-3D model has been set up for the region between $48.5^{\circ} \mathrm{N}-4^{\circ} \mathrm{W}$ and $52.5^{\circ} \mathrm{N}-$ $5.0^{\circ} \mathrm{E}$ using a 109 by 97 horizontal grid with resolution $5^{\prime}$ longitude (approx. $5.6 \mathrm{~km}$ ) by 2.5' latitude (approx. $4.6 \mathrm{~km}$ ) and with 5 vertical sigma coordinate layers. It has been run to 
simulate the annual cycle of carbon, inorganic and organic nutrients $\left(\mathrm{NH}_{4}, \mathrm{NO}_{3}, \mathrm{PO}_{4}, \mathrm{SiO}_{2}\right)$, phytoplankton (diatoms, nanoflagellates, Phaeocystis), bacteria and zooplankton (microzooplankton, copepods) in the southern North Sea and the Channel under realistic forcing. The consideration of different forms (3-4) for each phytoplankton species allows to account for variable $\mathrm{C}$ : $\mathrm{Chl}$ ratio.

Benthic organic matter degradation and nutrient $(\mathrm{N}, \mathrm{P}, \mathrm{Si})$ recycling were calculated by the algorithms developed by Billen et al. (1989). These algorithms, by solving steady-state diagenetic equations expressing the mass balance of organic $C$, oxygen and inorganic forms of $\mathrm{N}$ and $\mathrm{P}$ in the sedimentary column, calculate the fluxes of $\mathrm{NO}_{3}, \mathrm{NH}_{4}$ and $\mathrm{PO}_{4}$ across the sediment-water interface resulting from a given sedimentation flux of POM. The processes described included: organic matter degradation, associated $\mathrm{NH} 4$ and $\mathrm{PO}_{4}$ release, $\mathrm{O}_{2}$ consumption, nitrification and denitrification, $\mathrm{PO}_{4}$ and $\mathrm{NH}_{4}$ adsorption onto organic material, mixing in the interstitial and solid phases, and accretion of the sedimentary column by inorganic matter sedimentation. First-order kinetics described biogenic silica dissolution and release of DSi to the water column.

The PAR attenuation coefficient is modelled as function of: (i) non-algae particle concentration, (ii) chlorophyll $a$ concentration computed by the model, (iii) coloured dissolved organic matter (CDOM) absorption at $443 \mathrm{~nm}$ estimated from salinity computed by the model and (iv) depth. The non-algae particle concentration is estimated from total Suspended Particulate Matter (SPM) minus a fraction (function of the simulated chlorophyll $a$ concentration) representing the algae contribution. A SPM two-month climatology, spatially averaged to match the model grid cells, has been built from 1997-2003 SeaWiFS images using the algorithm of Nechad et al. (2003). Between 2-monthly data, SPM is interpolated.

For this application, open boundary conditions for temperature, salinity and nutrients from the POLCOMS-ERSEM model were used. The supplied ECMWF meteorological forcing (see 3.3) was used. Atmospheric deposition was not included. A spin up period of 2 years was sufficient to reach a stable repeating cycle of the pelagic variables.

\subsection{France - ECO_MARS3D [FR model]}

MARS3D (in workshop terms FR) is a three-dimensional circulation model developed at Ifremer by Lazure and Dumas (2008), which uses a finite-difference scheme to solve the primitive Navier-Stokes equations under both hydrostatic and Boussinesq assumptions. The domain simulated in this study extends from the south of Brittany $\left(47.5^{\circ} \mathrm{N}, 5.6^{\circ} \mathrm{W}\right)$ to north of the river Rhine plume $\left(52.5^{\circ} \mathrm{N}, 5.0^{\circ} \mathrm{E}\right)$. The grid is in spherical coordinates, with regular $4 \mathrm{~km}$ square meshes. The water column is divided into 12 sigma layers. The biogeochemical model is an extension of the NPZD model type but excludes variation of intracellular nutrient content. The biogeochemical cycles of carbon, nitrogen (with nitrate and ammonium treated separately), silicon and phosphorus are modelled, together with three bulk phytoplankton classes (diatoms, dinoflagellates, nanoflagellates) and two bulk zooplankton (micro- and mesozooplankton). Oxygen concentration, as a critical indicator of the eutrophication level, is also modelled. A specific module for Phaeocystis has been added, which is based on the MIRO model implementation (Lancelot et al., 2005), but with only four state variables (two kinds of solitary cells, colonial cells and mucuous matrix). Erosion and deposition processes of organic and inorganic matter occur at the interface of the water column and a multi-layer sedimentary bed. Remineralisation processes occur in the sediment and in the water. As swell forcing is not yet incorporated in the erosion module of ECOMARS3D, the predicted SPM is too low in some areas of the domain. This leads to time shifts in the growth of autotrophs. Thus the SPM distribution used in the assessment of the light extinction was prescribed as monthly composites of the sea surface mineral SPM, constructed from SeaWiFS-derived data and then interpolated to daily values to force the model. In regions of freshwater influence, especially near the coasts and inside estuaries, the satellite forcing is not accurate, or unavailable; in these ROFIs, satellite derived SPM is replaced by SPM computed in the model by transport and sedimentation of the river SPM inputs. Full details about the model implementation and its validation are given in Vanhoutte-Brunier et al. 


\subsection{Germany - ECOHAM4 [DE model]}

The coupled physical-biogeochemical or ecosystem model ECOHAM4 (in workshop terms DE model) relies on, and is an extension of the previous ECOHAM3 model which was used to calculate nitrogen and carbon budget in relation to NAO conditions (Pätsch and Kühn, 2008). The ECOHAM version which is used for the nutrient reduction simulations in this paper is an extension of this version with the focus on eutrophication applications. Therefore the nutrient cycles for phosphorus and silicon are included in this new ECOHAM4 version. Special attention is given on the representation of the seasonal oxygen dynamic (Müller et al., in prep.). The physical part is based on the hydrodynamic model HAMSOM (Pohlmann, 1996). The biogeochemical part represents the pelagic and benthic cycles of carbon, nitrogen, phosphorus, silicon and oxygen. The state variables included are: the functional phytoplankton groups diatoms and flagellates, micro- and mesozooplankton, slowly and fast sinking detritus, labile and semi-labile dissolved organic matter and bacteria, dissolved inorganic carbon (DIC), alkalinity and oxygen, as well as the nutrients nitrate, ammonium, phosphate and silicate. Additionally, a module for the equilibrium chemistry of inorganic carbon is implemented, so that the model is able to calculate the air-sea flux of $\mathrm{CO}_{2}$. For phytoplankton, zooplankton and bacteria fixed, but different $\mathrm{C}: \mathrm{N}: \mathrm{P}$ ratios were prescribed. The C:N:P ratios of detritus and labile DOM can evolve freely. The benthic remineralisation processes are parameterized in a very simple way: the sediment is represented by a horizontal layer (without vertical extension) where the sedimenting material is collected and remineralised, using different remineralisation rates for organic carbon, nitrogen, phosphorus and silicon (opal). The coupled benthic nitrification/denitrification is bound to the oxygen consumption due to carbon remineralisation.

The model area comprises the whole North Sea and large parts of the Northwest-European Shelf $\left(15^{\circ} \mathrm{W}-14^{\circ} 15^{\prime} \mathrm{E}, 47^{\circ} 40^{\prime} \mathrm{N}-64^{\circ} \mathrm{N}\right)$. The horizontal resolution is about $20 \mathrm{~km}$, with $24 \mathrm{z}-$ coordinate layers in the vertical ( $5 \mathrm{~m}$ thickness in the upper $50 \mathrm{~m}$, below increasing). In shallow areas, phytoplankton growth is limited due to self-shading and light attenuation by silt. To include the latter effect, daily silt data from Heath et al. (2002) were interpolated to the grid and prescribed at each grid point. River loads, atmospheric nitrogen deposition and boundary conditions are those supplied for all participants.

\subsection{The Netherlands - Delft3D-GEM [NL model]}

The Southern North Sea Generic Ecological Model (GEM, in workshop terms NL) is an application based on the Deltares (formerly, WL | Delft Hydraulics) software for modelling water quality and aquatic ecology: Delft3D-ECO. Delft3D-ECO (in workshop terms NL model) calculates the advective and dispersive transport of substances, biogeochemical processes and loads, accumulates fluxes and computes resulting concentrations for each time-step.

Delft3D-GEM simulates the nutrient cycles of carbon, nitrogen, phosphorus, silicon and dissolved oxygen. As dissolved inorganic nutrients, the following state variables are included in the model: nitrate $\left(\mathrm{NO}_{3}\right.$, representing the sum of nitrite and nitrate), ammonium $\left(\mathrm{NH}_{4}\right)$, phosphate $\left(\mathrm{PO}_{4}\right)$ and dissolved silicate $\left(\mathrm{SiO}_{4}\right)$. Four functional phytoplankton groups are simulated: diatoms, flagellates, dinoflagellates and Phaeocystis, with three phenotypes each to account for adaptation to environmental conditions by phytoplankton (different types under different conditions of resource limitation). Transport, transformation and recycling of nutrients are modelled explicitly. Grazing of algae and by benthic suspension feeders and zooplankton is parameterized by phenotype-dependent rates. Sedimentation of algae and organic matter and extinction of light by particulate matter, algae and humic substance are also modelled explicitly. 
The GEM configuration includes the parameter settings that were calibrated for the North Sea and that have proven to be applicable for a range of other coastal ecosystems as well (Blauw et al., 2009). This paper also includes a detailed description of the model equations. Application specific to the North Sea have been described by Los \& Bokhorst (1997) and De Vries et al. (1998). Los et al. (2008) present the set-up and results of the model application for the 2007 OSPAR workshop in detail, whereas Los and Blaas (this issue) discuss the evolution towards Delft3D GEM over the past 15 years in terms of biogeochemical model skill.

For the present study, boundary conditions for temperature, salinity and nutrient have been derived from the POLCOMS-ERSEM model, as described below. At the surface, the Delft3D Flow hydrodynamic simulation that underlies the transport model was forced by the ECMWF data in addition to Dutch Met Office (KNMI) observation time series of light vessel Goeree off the southern coast of Holland. Weekly-averaged SPM concentrations were derived from a process-based 3D mud transport model of the southern North Sea based on a grid and hydrodynamics identical to those used for the eutrophication simulations. The mud transport model includes boundary and river sediment loads, loads from cliff erosion and wave- and current induced resuspension and transport. It has been calibrated with observed SPM data in the Dutch coastal zone, using both long-term low-frequency time series and short-term high-frequency time series. For more information is referred to Van Kessel et al. (2009). The model was spun up for a period of 5 years until an equilibrium in the pelagic variables was achieved.

\subsection{United Kingdom - Cefas GETM-BFM [UK-Cefas model]}

The General Estuarine Transport model (GETM, see www.getm.eu) has been coupled to the Biogeochemical Flux Model (BFM, see www.bfm.cmcc.it) to provide a new coupled model to improve understanding of, and predict changes in, the North Sea ecosystem structure and function. The GETM model is a full 3D hydrodynamical model that uses the General Ocean Turbulence Model (GOTM, see www.gotm.net) for the vertical turbulence structure. Spherical coordinates are used in the horizontal plane, while general vertical coordinates are used in the vertical (equidistant in shallow water and contracted near the surface and the sea bed in deeper water). The hydrostatic equations are solved on an Arakawa $C$ grid in the horizontal using a mode splitting technique. Elevations at the boundary are derived from Topex Poseidon satellite altimetry data, and the model allows for drying and flooding of tidal flats. For further detail see Burchard and Bolding (2002) and Stips et al. (2004).

The BFM (in workshop terms UK-Cefas) is a development of the model ERSEM III (European Regional Seas Ecosystem Model, see Baretta et al., 1995 and Vichi et al., 2004), and describes the dynamics of the biogeochemical fluxes within the pelagic and benthic environment. The BFM model simulates the cycles of $\mathrm{C}, \mathrm{N}, \mathrm{P}, \mathrm{Si}$ and $\mathrm{O}$ and allows for variable internal nutrient ratios inside organisms, based on external availability and physiological status. The model applies a functional group approach and contains four phytoplankton groups, four zooplankton groups and five benthic groups. Pelagic and benthic aerobic and anaerobic bacteria are also included. The sediment is subdivided into three layers: an oxic layer, a denitrification layer and an anoxic layer. The three layers have a fixed total depth. The oxic and denitrification layer have variable width, calculated by the model, while the remaining depth defines the anoxic layer width. To improve the under-water light regime, temporally and spatially varying SPM concentrations were calculated as a function of the local sea-bed composition and wave-shear stress, with wave height and period calculated from the wind forcing data using an equilibrium JONSWAP formulation subject to a shoaling function, and wave-orbital velocities calculated using linear wave theory. An improved SPM model is under construction (van der Molen et al., 2009). Both GETM and BFM are public-domain models.

The set-up used for this application consisted of a North Sea and Channel area model (domain $5.8^{\circ} \mathrm{W}$ to $18.0^{\circ} \mathrm{E}, 48.4^{\circ} \mathrm{N}$ to $60.3^{\circ} \mathrm{N}$ ), on a spherical grid with approximately 6 nautical mile resolution, with 25 layers in the vertical. Boundary conditions were derived from the 
POLCOMS-ERSEM model, described below, for temperature, salinity and nutrients at the open boundaries. The supplied ECMWF meteorological forcing was used. Atmospheric deposition was not included. The model was spun up for a period of 8 years until an equilibrium in the pelagic variables was achieved.

\subsection{United Kingdom - POL POLCOMS-ERSEM [UK-POL model]}

The coupled hydrodynamic-ecosystem model POLCOMS-ERSEM (in workshop terms UK$\mathrm{POL}$ ) was set up for the Atlantic Margin region of the NE Atlantic, extending from $20^{\circ} \mathrm{W}$ to $13^{\circ} \mathrm{E}$ and $40^{\circ} \mathrm{N}$ to $65^{\circ} \mathrm{N}$. The physics model, the Proudman Oceanographic Laboratory Coastal Ocean Modelling System (POLCOMS), is a three-dimensional baroclinic B-grid model (Holt and James, 2001; Proctor and James, 1996) solving for hydrodynamics, temperature and salinity. Tides are included by using open boundary conditions of 15 tidal constituents and by adding in the equilibrium tide. Large-scale non-tidal dynamics are accounted for by including barotropic currents, elevation, temperature and salinity boundary data, taken from the Forecasting Ocean Assimilation Model (FOAM, Bell et al., 2000). ECMWF operational analysis data of mean sea level pressure, wind speed and direction, air temperature, relative humidity and cloud cover are used as surface forcing. Details of running POLCOMS on the Atlantic Margin domain are given by Wakelin et al., (2009).

The European Regional Seas Ecosystem Model (ERSEM) calculates carbon, nitrogen, phosphorus, and silicon cycling in a coupled pelagic-benthic system using 51 pelagic and 44 benthic state variables. The coupling between the POLCOMS and ERSEM models is described by Allen et al. (2001), while the version of ERSEM used here is essentially that applied by Blackford et al., (2004). The ERSEM formulation used here is similar to the BFM (UK-Cefas) model.

To represent the suspended particulate matter (SPM) and coloured dissolved organic matter (CDOM), a simple interpolation-based assimilation of observations is used. An Inherent Optical Property (IOP) variable is introduced and relaxed to observations (monthly composites of non-biotic absorption from SeaWiFS) on a seven-day time-scale. This removes uncertainties in trying to model SPM and CDOM due to the many unknowns (settling velocities, sea bed dynamics, sources/sinks, chemistry etc.).

The Atlantic Margin implementation of POLCOMS-ERSEM uses a spherical polar grid of resolution $1 / 9^{\circ}$ latitude by $1 / 6^{\circ}$ longitude $(\sim 12 \mathrm{~km})$ with 34 sigma-coordinate levels in the vertical. POLCOMS is spun up from 1987 to the end of 2000 to provide initial temperature and salinity fields for the reference run and both of the $50 \%$ and $70 \%$ (optional) reduction scenarios. For each run, the coupled POLCOMS-ERSEM model is further spun up for three years using 2001 forcing data followed by three years using 2002 forcing. Using the 2002 forcing data, one final year is run in each case to give results to provide boundary and initial conditions for the other participant's models. The POLCOMS-ERSEM results shown here are from reruns using 8-day composite Inherent Optical Property data from SeaWiFS, in place of the monthly composites.

\section{Workshop Set-up}

The programme of work was designed to meet specific OSPAR requirements. These were "to carry out nutrient reduction scenarios for 2002 showing the predicted consequences for selected eutrophication assessment parameters in problem areas with riverine nutrient reductions of 50\% (obligatory) and 70\% (voluntary) since 1985 (the OSPAR reference year), or any other voluntary additional reduction scenarios necessary in order to bring the assessment variable below the relevant threshold. The reductions in phosphate and ammonium must take into account, by country, reductions already evident between 1985 and 2002...". In order to facilitate the work programme the following data were provided: common 
forcing data, boundary conditions, riverine nutrient loads, and calibration and validation data. This was done in order to achieve comparable model results.

\subsection{River loads}

Daily nutrient loads were provided for 48 rivers in total, covering all the major rivers leading into the North Sea as well as the Irish Sea. UK rivers were grouped over small geographical areas. It is important to emphasise that the nutrient reduction scenarios are based on reductions of riverine inputs in the reference year 2002, taking into account the load reductions achieved by Contracting Parties in 1985 - 2002. This means that first the additional reduction percentage had to be calculated which was needed in 2002 to achieve a $50 \%$ and $70 \%$ reduction, in relation to 1985 levels for nitrogen and phosphorus. In order to achieve this additional reduction percentage between 1985 and 2002, the available river load data were grouped by country to estimate regionally differing reduction percentages. In Fig. 3 the resulting time series for $\mathrm{PO}_{4}, \mathrm{NH}_{4}$ and $\mathrm{TO}_{x} \mathrm{~N}\left(\mathrm{NO}_{3}+\mathrm{NO}_{2}\right)$ are presented for each country.

(Fig. 3: about here)

Given the interannual variability for TOxN the 2002 and 1985 loads are considered as equal (no change). For $\mathrm{PO}_{4}$ and $\mathrm{NH}_{4}$ proportional reductions were calculated as follows:

1. Percentage change calculated between 1985 and 2002.

2. Rounded to nearest $10 \%$ interval to account for variability (uncertainty).

3. Only the countries with major rivers for which sufficient data were available were taken into account.

The resulting reductions achieved for the three nutrients under consideration between 1985 and 2002 are displayed in Table 1a for each country.

\section{(Tab. 1: $\quad$ about here)}

The river load reduction for a $50 \%$ (scenario 1, Table 1b) and a $70 \%$ (scenario 2, Table1c) reduction are also presented. For the hindcast run for the year 2002, the daily nutrient loads were provided, while for the reduction scenarios these river loads for 2002 were adopted according to Tab. $1 \mathrm{~b}$ and $1 \mathrm{c}$. No reduction was prescribed for the organic part of the load due to lack of data.

\subsection{Atmospheric Nitrogen deposition}

As further source of nutrients, atmospheric nitrogen deposition data were made available for incorporation into the ecosystem models. These data were provided by EMEP (Cooperative Programme for Monitoring and Evaluation of the Long-range Transmission of Air Pollutants in Europe). The data include the atmospheric dry and wet deposition of oxidized nitrogen compounds $\left(\mathrm{NO}_{\mathrm{x}}\right)$ as well as the atmospheric dry and wet deposition of reduced nitrogen $\left(\mathrm{NH}_{\mathrm{y}}\right)$, on a monthly basis. This was an improvement in comparison to the workshop in Hamburg 2005, where only annual data from EMEP could be used. Unfortunately, an inconsistency in the description of the atmospheric deposition data resulted in an 
underestimation of the input by a factor of 12 . This also includes the POLCOM-ERSEM simulation applied for the boundary conditions. However, atmospheric deposition of nutrients was not reduced in the reduction scenarios.

\subsection{Meteorological forcing}

The ECMWF Operational Forecast database for the years 2001 and 2002 was supplied to all groups for use as meteorological forcing data in their simulations. The data set comprises the standard meteorological data (sea-level pressure, dew point temperature, 2 meter temperature, 10 meter $u$ and $v$ wind components, total cloud cover) on a N80 spherical grid with a spatial resolution of $1.125 \times 1.125$ degrees horizontal grid in 6 hour time-steps.

\subsection{Boundary conditions}

In order to achieve a consistent set of boundary conditions for all model applications data were extracted from a wider area model whose domain covered the areas of all the other models. These boundary data were provided by the Atlantic Margin Model POLCOMSERSEM (UK-POL) for 51 pelagic variables for each boundary of the different national models (Fig. 2) on a daily basis. In addition, temperature and salinity boundary data as well as benthic initial conditions were provided. This data set was produced by applying the same atmospheric forcing, the river input and the atmospheric nutrient deposition as used by all participants for their national ecosystem model. This consistent dataset was not only provided for the standard run, but also for both reduction runs.

\subsection{Spin-Up}

As a spin-up procedure the following approach was proposed: to run each model repeatedly for one year sufficiently often (minimum: 3 times), to achieve a repeating annual cycle. The year 2002 using 2002 nutrient inputs and boundary conditions was recommended. The end state of this spin-up should be used as a starting condition for the reference (or standard) year 2002 and all reduction scenarios. The procedures adopted by each group are shown Tab. 2.

\section{(Tab. 2: $\quad$ about here)}

\subsection{Validation}

It is worth noting that all models used in the comparison had been subject to calibration and validation procedures using the supplied data. Furthermore, to aid evaluation of individual model performance a cost function was used (Radach and Moll, 2006). However, the large amount of data from the models and the generally low number of observations used to calculate the standard 'OSPAR cost function' (the normalized mean absolute error; Villars and De Vries, 1998) in addition to its low distinguishing power (see e.g. Los and Blaas, this issue) reduced its reliability. Therefore, the confidence attributed to the performance of an individual model is based primarily upon the outcome of the validation procedure rather than on the results of the cost function calculation. For a detailed description of the calibration and validation procedure see the ICG-EMO Workshop Report (OSPAR, 2008a). 


\section{Results}

In the presentation of the results the models are referred to by their workshop term, e.g. POLCOMS-ERSEM is referred to as UK-POL model.

\subsection{Net Primary Production}

In Fig. 4 the horizontal distributions of the net primary production (NPP) for the 2002 hindcast run by the different models are presented. For those models covering the whole North Sea, there are considerable differences between the UK-POL (Fig. 4a) and UK-Cefas (Fig. 4c) calculations on the one hand and the DE (Fig. 4b) and the NL (Fig. 4d) results on the other. One reason for the differences is the definition of NPP. For example, in the UK-Cefas and the UK-POL model NPP is calculated as carbon uptake by phytoplankton minus respiration and excretion, in other words, net carbon biomass production. This may imply a difference of approximately $50 \%$ in comparison to the NPP presented for the other model hindcasts, where NPP is calculated as the gross primary production (photosynthesis) minus respiration. While the UK-POL model exhibits highest net primary production values near the Dogger Bank and along the coast of Norway, the UK-Cefas model also shows regions of maximum NPP along the coast of Norway and between the UK and France as well as along the UK coast. From the continental coastal region northward there is a wide area with NPP values of up to $100 \mathrm{~g} \mathrm{C} \mathrm{m}^{-2} \mathrm{yr}^{-1}$. The UK-Cefas simulation in this study shows low primary production near the continental coast for three reasons: 1) use of a new, time-varying SPM model, which resulted in higher, more realistic SPM concentrations, but in combination with light efficiency settings for phytoplankton calibrated for much higher underwater light levels; 2) a too small nutrient-stress dependent sinking rate of diatoms reduced the recycling of $\mathrm{Si}$, which was transported out of to the system during the 8 years of spin up resulting in severe Si limitation; 3) the absence in the model of a non-grazable functional group like Phaeocystis colonies, which can escape from being top-down controlled. The main reason for the low primary production along the continental coast in the UK-POL results is that values of IOP (SPM and CDOM) are too high in this region, restricting the light field.

\section{(Fig. 4: $\quad$ about here)}

The DE (Fig. 4b) and the NL (Fig. 4d) simulations show the same pattern in the distribution of the net primary production, with lower values in the central and northern North Sea and higher values in the southern North Sea. In the southern Continental Coastal Region, an area with net primary production values above $250 \mathrm{~g} \mathrm{C} \mathrm{m}^{-2} \mathrm{yr}^{-1}$ stretches from Belgium up to the northern tip of Denmark. Near the inlets of the rivers Rhine and Elbe the values reach maxima of up to $350 \mathrm{~g} \mathrm{C} \mathrm{m}^{-2} \mathrm{yr}^{-1}$. Further local maxima occur in vicinity of the rivers Seine, Thames and Humber. Due to its finer grid size the NL model is able to exhibit finer structure within this pattern, e.g. small areas with net primary production of $300 \mathrm{~g} \mathrm{C} \mathrm{m}^{-2} \mathrm{yr}^{-1}$ further offshore and therefore not directly linked to the overall gradient with higher production towards the coast. However, both models identify a local maximum in the south-western part of Denmark. The simulations of the smaller domain models which represent the Channel region and the southern North Sea (FR (Fig 4e) and BE (Fig 4f) model) identify a northern area of lower production of less than $100 \mathrm{~g} \mathrm{C} \mathrm{m}^{-2} \mathrm{yr}^{-1}$, roughly stretching from Cherbourg towards the middle of the Channel at the Belgium coast. Besides, they show spots of high NPP in the Thames region as well as in the vicinity of the Seine and the Rhine. Locally, for the Thames and the Seine region, the BE model simulation gives higher NPP values of about $350 \mathrm{~g} \mathrm{C} \mathrm{m}^{-2} \mathrm{yr}^{-1}$ than the FR model, which are also met by the NL model (Fig. 4d). However, the NL model simulation exhibits these higher values near the coast not only for the Thames region but also for a smaller region along the coast of the UK and France. 


\subsection{Difference between Standard run and the $50 \%$ reduction scenario}

The differences in the NPP, obtained by subtracting the results of the $50 \%$ reduction from the standard run and relating it to the standard run are presented in Fig. 5. Both the DE (Fig. $5 b$ ) and the NL (Fig. 5d) simulations, which showed a similar structure in the horizontal distribution of the NPP (Fig. 4), identify an area of maximum change in NPP of up to $-25 \%$ stretching from the northern coast of Denmark toward the Humber and Thames estuaries. Even though the UK-POL model showed a different horizontal distribution for the NPP, the maximum differences (Fig. 5a) exhibit a similar pattern as the DE and the NL simulations. The maximum difference is identified near the Thames and the Humber with values of up to $-30 \%$. In contrast to these model results, the UK-Cefas model yields the highest differences between the hindcast and the 50\% reduction run along the continental coastal region. Especially near the Elbe estuary a change of up to $-40 \%$ was found.

\section{(Fig. 5: about here)}

Locally, the NL model (Fig. $5 d$ ) shows changes of up to $-45 \%$ in the Thames, which is in agreement with the BE (Fig 5f) simulation. In the BE simulation this Thames region with high differences in NPP is larger than in the NL simulation. In addition, the BE simulation also exhibit regions with high reduction in the NPP in the Bay of Seine. The FR model gives patterns of reduction in front of the Thames, Seine and Scheldt rivers similar to those displayed by the BE model, but some $10 \%$ lower.

\subsection{Comprehensive Procedure Assessment}

In order to achieve comparable model results, a number of target areas were defined (Fig. 6), which were a subset of the water bodies to which the 2002 CP assessment was applied. For these target areas the model results are presented as mean values, calculated from the hindcast run and the reduction scenarios (Fig. 7). These values are scored against the target area-specific thresholds which the contracting parties used in the first application of the CP in 2002. The rationale for this approach is to put the model results into the context of the OSPAR CP allowing comparison with monitoring results used in the 2002 assessment. In addition, the model results were used to indicate the direction of change in the value of an assessment variable as a result of nutrient reductions.

It should be noted that the applied reduction in riverine nutrient loads takes into account any reduction already achieved in 2002 (Tab.1). This means that the specific reduction scenarios applied need to be taken into account in the interpretation of the resulting concentration level for each target area.

\subsubsection{Target Areas}

The target areas (Fig. 6) were designed to replicate the location and dimensions of the actual water bodies used by contracting parties in the CP. Aggregated simulation results from the hindcast simulation for 2002 and the two reduction scenarios were analysed for each area.

(Fig. 6: about here) 


\subsubsection{Belgium B-C1}

The Belgian target area corresponds to the coastal waters of the Belgian Exclusive Economic Zone (BEEZ) whose mean salinity (according to model results for the period 19932003) is between 30 and 34.5. The Belgian Coastal Waters (BCW) have strong tidal currents where water of Atlantic origin is mixed with riverine freshwater inputs. BCW are characterized by generally well-mixed, very turbid waters with elevated nutrient concentration and highbiomass algal blooms (mainly the Haptophycea Phaeocystis globosa). The nutrient distribution in the area is the result of inputs from the Atlantic and from rivers. In consequence, the area is characterized by high nutrient concentration close to the coasts and lower concentration offshore. In particular, BEEZ waters are influenced directly by the Scheldt river (and other small Belgian tributaries) but also indirectly by French river waters (mainly the Seine) discharging in the Atlantic waters and by dispersion of the Rhine/Meuse river waters (Lacroix et al., 2004; Lacroix et al., 2007). As a result of significant riverine nutrients enrichment since the 1960s, eutrophication occurs in BEEZ waters (Lancelot et al., 2007) and is manifested as massive development of Phaeocystis colonies. These blooms are sustained by freshwater inputs deficient in silicon but enriched in $\mathrm{N}$ and $\mathrm{P}$ (Rousseau et al., 2004).

Following the second OSPAR assessment, the BCW (target area B-C1) was classified as a PA (OSPAR, 2008b) mainly because winter DIN and DIP exceed the assessment levels. From in situ data collected in January 2003, Brion et al. (2008) show winter DIN concentration higher than $20 \mu \mathrm{mol} \mathrm{N} / \mathrm{l}$ in the Belgian Coastal Zone, above the assessment threshold $(15 \mu \mathrm{mol} N / \mathrm{l})$. All six model results show a decline in the mean winter DIN concentration with the reduction of the nutrient supply. While the BE, the NL and the UK-POL model yield DIN concentrations above the assessment level (between 23 and $19.4 \mu \mathrm{mol} \mathrm{N} / \mathrm{l}$ ), the values for all other model are lower. The DIN values from the UK-POL model fall below the threshold of $15 \mu \mathrm{mol} N / \mathrm{l}$ for the $50 \%$ reduction scenario. In contrast, the mean winter DIN concentration from the NL $50 \%$ reduction simulation comes close to the threshold; both the NL and the BE model fall below this level only for the $70 \%$ reduction scenario.

The Belgium coast B-C1 is influenced by loads from the Scheldt river (its input is accounted for in Tab. 1 as part of the Netherlands input, similar to the Rhine) and the French rivers. As for DIN, Brion et al. (2008) show winter DIP concentration in January 2003 higher than 1 $\mu \mathrm{mol} \mathrm{P} / \mathrm{l}$ in the major part of the Belgian Coastal Zone, above the assessment threshold (0.8 $\mu \mathrm{mol} P / \mathrm{l})$. Since no DIP reduction was applied for Dutch rivers in either scenario and only a $20 \%$ DIP reduction for French rivers within the $70 \%$ reduction scenario, the simulated DIP concentrations show nearly no response in the reduction runs. However, it should be noted, that there is no agreement between absolute values of assessment variables between the different models. As with the mean winter DIN concentration for B-C1, both the BE and the $\mathrm{NL}$ models show the highest values for the hindcast run $(1.2$ and $0.92 \mu \mathrm{mol} P / \mathrm{l})$ in comparison to the other models, which gave values below the threshold of $0.8 \mu \mathrm{mol} P / \mathrm{l}$.

For the mean summer chlorophyll concentration at surface, the threshold is not exceeded by any of the hindcast simulations. The chlorophyll concentrations from the models vary by a factor of 3 for the hindcast, from $4.69 \mu \mathrm{g} \mathrm{Chl} / \mathrm{l}$ for the NL model to $1.65 \mu \mathrm{g} \mathrm{Chl/l}$ for the UK$\mathrm{POL}$ model. Also the response to the DIN reduction in the river loads is minor. The overall percent change is only $8.4 \%$ for scenario 1 and $14.7 \%$ for scenario 2 ; these values are relative to already low summer chlorophyll concentrations. 


\subsubsection{France F-C2}

This region along the French coast of the eastern English Channel is a shallow coastal area with a maximum depth of $40 \mathrm{~m}$. Its south-western part comprises of the Bay of Seine, which receives the rivers Seine, Orne, Vire and Douve. The Seine river, which drains a basin of $75000 \mathrm{~km}^{2}$, has a mean discharge of $450 \mathrm{~m}^{3} / \mathrm{s}$ (ranging from $2000 \mathrm{~m}^{3} / \mathrm{s}$ during floods to 100 $\mathrm{m}^{3} / \mathrm{s}$ at lowest discharge). This freshwater input induces a small plume, with strong horizontal and vertical gradients and an enrichment of nutrients $(\mathrm{N}, \mathrm{P}, \mathrm{Si})$. The annual mean load of dissolved nitrogen, dissolved silicon and dissolved phosphorus are about 80500 ,

46300 and 8400 tons, respectively (Ménesguen et al., 1995). Other rivers flowing into the bay (Orne, Vire and Douve) are responsible for total nitrogen and phosphorus loads of about $10 \%$ and $2 \%$, respectively, of the Seine input. As a consequence of this enrichment, high NPP is observed in the river plume with maximum chlorophyll concentration up to $40-70 \mu \mathrm{g}$ Chl/l (Aminot et al., 1997). Diatoms are the dominant phytoplankton group. They appear in spring and maintain high abundances into the autumn. Flagellates may become abundant in late summer. Since 1983, a dinoflagellate producing diarrhoeic toxin, Dinophysis cf. acuminata, is regularly observed in the Bay of Seine, and forces periods of closure of shell fisheries. Blooms of this species can reach $10^{6}$ cells/l. Between the Seine estuary and the Straits of Dover, some minor rivers (Somme, Authie, Canche, Liane) add about half the freshwater brought by the river Seine into the F-C2 target area. A succession of small tidal residual gyres transport these mixed, fresher and enriched waters along the French coast in a narrow strip limited by a front. The north-eastern part of F-C2 target area is then richer in chlorophyll (Quisthoudt, 1987). Eutrophication of the F-C2 target area has been clearly identified by French modelling studies (e.g. Guillaud and Ménesguen, 1998) and linked to the historical evolution of the watershed occupation of the river Seine (Cugier et al., 2005).

Following the first application of the OSPAR CP the target area F-C2 is classified as a PA in the vicinity of the river Seine in the south-western part, whereas the eastern part has a NPA status. The winter DIN threshold $(15 \mu \mathrm{mol} N / \mathrm{I})$ is the same as for the offshore box NL-O2. Similarly to the results for target area B-C1, the BE, NL and the UK-POL model all exceed the threshold. Also similar to B-C1, the UK-POL model reaches a DIN value below the threshold for the $50 \%$ reduction run. For the BE and the NL model the $50 \%$ reduction does not change the status, even though the BE model gives a value $(15.12 \mu \mathrm{mol} \mathrm{N} / \mathrm{l})$ very close to the threshold. The remaining models yield mean winter DIN values below the threshold for F-C2. For the winter DIP concentration, F-C2 has the highest threshold $(1.2 \mu \mathrm{mol} P / \mathrm{l})$ in comparison to the other target areas. All results display values well below $1 \mu \mathrm{mol} P / l$ in the hindcast run for 2002, with little change in the reduction runs. This is due to the fact that $\mathrm{PO}_{4}$ is not reduced in the French rivers in the $50 \%$ reduction and only by $20 \%$ in the $70 \%$ reduction run (Tab. 1). For the mean summer chlorophyll concentration only the simulation from the NL model exceeds the threshold and also does so in reduction runs. The other models exhibit chlorophyll values well below the threshold. The UK-Cefas model shows no further reduction in the chlorophyll values beyond the $50 \%$ reduction, where the mean summer chlorophyll concentration was slightly reduced from 3.1 to $2.9 \mu \mathrm{g} \mathrm{Chl/l}$.

\subsubsection{Germany G-C1}

The target area G-C1 is located within the German Bight, a shallow bight with a water depth mostly less than $40 \mathrm{~m}$. Within this coastal water body salinities range from 30 to 34.5. The sea bed topography is dominated by the Elbe Rinne, an old river bed which runs in a southeast-northwest direction. The continental coastal current, a mixture of Atlantic water and continental runoff, mainly from the Rhine, enters the box from the west and leaves it northward (Van Beusekom et al., 1999). Due to its location at the south-eastern edge of the North Sea, and in combination with the anticlockwise residual circulation within the North 
Sea, the German Bight has a relatively long flushing time. The mean flushing time was calculated to be about 33 days, with a range from 10 to 56 days (Lenhart and Pohlmann, 1997). Since longer flushing times lead to enhanced sedimentation of organic material, this adds to the problem of subsequent oxygen depletion (Dethlefsen \& von Westernhagen, 1983). The main river discharges stem from the Elbe as well as from Weser and Ems. The Elbe in particular carries large amounts of nutrients, which cannot be utilised in the vicinity of the inlet due to light limitation as a result of the high turbidity.

The mean winter DIN concentrations at the surface from all four models that provide values for this target area are high. This is due to the high river nutrient load from the Elbe. The NL and UK-Cefas standard runs yields winter concentrations which are just below the threshold of $24 \mu \mathrm{mol} \mathrm{N} / \mathrm{l}$, while the values from the UK-POL $(47.9 \mu \mathrm{mol} \mathrm{N} / \mathrm{l})$ and the DE model (36.1 $\mu \mathrm{mol} \mathrm{N} / \mathrm{l})$ are well above the threshold. With the $50 \%$ reduction the DE result fall below the winter DIN threshold. In contrast, the UK-POL model remains above the threshold in the 50 $\%$ reduction, falling below only within the $70 \%$ reduction.

Only the DE model realistically reflects the large riverine phosphorus input into the G-C1 area with high DIP winter surface concentration of about $1.3 \mu \mathrm{mol} P / l$, well above the threshold of $0.9 \mu \mathrm{mol} P / l$. The other models start with concentrations of around $0.6 \mu \mathrm{mol} P / l$, considerably below the threshold. Since the river load for DIP is not reduced for the German rivers in the $50 \%$ reduction (Tab. 1), the model also shows hardly any decrease in the concentration. The slight decrease that can be observed is likely to be to related to reductions elsewhere along the continental coast. In contrast, the $70 \%$ reduction has an effect in all model results reflecting the $40 \%$ DIP reduction applied to German rivers. Nevertheless, for the DE model the resulting DIP winter concentration does not fall below the threshold.

The mean summer chlorophyll concentrations at the surface obtained by the DE and NL models are above the threshold of $3 \mu \mathrm{g} \mathrm{Chl/l}$. Even in the reduction scenarios the simulated summer chlorophyll concentration does not fall below the threshold for either models. While the NL model already shows a strong reaction to the reduced nutrient supply in the $50 \%$ reduction, and comes close to the threshold in the $70 \%$ reduction, the DE model shows hardly any response to the $50 \%$ reduction. The final value reached for the $70 \%$ reduction in the DE model is only slightly lower than the value reached in the NL simulation for the $50 \%$ reduction. The UK-Cefas model gives a chlorophyll concentration just below the threshold and shows a linear response to the river load reduction. The UK-POL model has the lowest mean surface summer chlorophyll of all models for the target area G-C1 and shows nearly no response to the river load reduction.

(Fig. 7: about here)

\subsubsection{The Netherlands - NL-C2 and NL-O2}

Target area NL-C2 corresponds to coastal waters between the delta of the Rhine and Meuse to the south and the Wadden Sea inlets to the North. Since these waters are primarily influenced by the discharge of the rivers Rhine and Meuse, the salinity is below 34.5, occasionally even below 30 and the nutrient concentrations are high. A residual transport northward along the coastal zone of a few tens of $\mathrm{km}$ width is found. Average SPM concentrations in this zone are about $5 \mathrm{mg} / \mathrm{l}$ increasing shoreward to over $25 \mathrm{mg} / \mathrm{l}$ due to trapping of SPM in the estuarine overturning circulation (e.g. Eisma \& Kalf, 1987). With the 
exception of haline stratification events during high river discharges, the waters are vertically well-mixed due to the tidal currents. As is the case in the Elbe outflow (G-C1, see above), in most models available light tends to be limiting for primary production, restricting short-term nutrient utilization. As in the Belgian coastal waters, algal blooms are dominated by diatoms in early spring and autumn while flagellates (including Phaeocystis spp.) come in late spring (Baretta-Bekker et al., 2009)

The high nutrient input by the Rhine and the Meuse in the vicinity of the target area NL-C2 is reflected in the high OSPAR threshold levels: $30 \mu \mathrm{mol} \mathrm{N} / \mathrm{l}$ for DIN and $0.8 \mu \mathrm{mol}$ P/I for DIP. The four model runs for NL-C2 show a linear reduction in the winter DIN concentration with increasing reduction in the DIN load. While the results of the NL, the DE and the UK-POL models are slightly above the threshold for the 2002 hindcast, the mean winter DIN concentration values fall below the threshold for the $50 \%$ reduction. The UK-Cefas model gives a DIN value well below the threshold already for the hindcast run $(17.1 \mu \mathrm{mol} N / \mathrm{l})$.

For the interpretation of the mean winter DIP concentration one has to consider that no riverine DIP input reduction had been applied, even in the $70 \%$ reduction scenario (Tab. 1) for this target area. Therefore it is not surprising that there are only minor changes in the mean winter DIP concentration obtained by the four models used in the reduction runs. In essence, the models that start with DIP winter values above the threshold in the standard run remain above the threshold in the reduction scenarios. Only the DE model shows a slight reduction in the $70 \%$ reduction run, while the UK-Cefas model exhibits a slight decrease in the DIP winter value for the $50 \%$ scenario run but no further reduction for the $70 \%$ scenario.

With a mean summer chlorophyll value in the surface layer of $5.85 \mu \mathrm{g} \mathrm{Chl} / \mathrm{l}$ the NL model displays the highest value of all models in the hindcast run for this target area, nevertheless this value represents only about $1 / 3$ of the threshold value $(15 \mu \mathrm{g} \mathrm{Chl} / \mathrm{l})$. In general, little change in chlorophyll concentrations was observed for the reduction scenarios. This could be due to the lack of any reduction in DIP load for the rivers that enter this area. Alternatively, the high SPM concentration in this area may lead to light- rather than nutrient limitation.

The offshore target area NL-O2 includes the Oyster Grounds, an area of approximately $45 \mathrm{~m}$ depth. This area is located north of the Frisian Front (which separates the coastal from offshore waters north of the Wadden Islands) and south of the shallower Dogger Bank. Salinities are above 34.5 and due to the larger depth and relatively weak tidal currents it is subject to thermal stratification in summer. The confluence of waters from the Southern Bight and UK coastal and offshore waters transported southward and eastward, provides a continuous nutrient supply. Due to the weak vertical mixing the area acts as a temporary deposition area of SPM (Van Raaphorst et al., 1998). Due to relatively low SPM concentrations in this area the euphotic zone extends below the summer thermocline which permits the growth of phytoplankton not only in the surface mixed layer, but also in the bottom mixed layer (e.g. Peeters et al., 1995). Compared to coastal waters, dinoflagellates contribute more to the algal population in late summer/early autumn (Baretta-Bekker et al., 2009). In years with sufficiently strong and prolonged stratification, oxygen depletion in the bottom mixed layer may occur towards the end of summer due to the decay of detritus (Weston et al., 2008). These conditions are promoted by northeasterly winds that often accompany calm and warm summer weather and reduce the flushing of the Oyster Grounds.

All model results are below or just at the thresholds for DIN, DIP and chlorophyll in the target area NL-O2, thus suggesting a non-Problem Area classification. For the simulated DIN concentration, only the NL model shows hardly any change, while all other models show a 
nearly linear response in the mean winter DIN concentration in relation to the load reduction. The mean winter DIP results from the DE model coincide with the threshold for the standard and the $50 \%$ reduction run, but fall below the threshold in the $70 \%$ reduction scenario. Although riverine DIP inputs for the Netherlands are not reduced even in the $70 \%$ reduction (Tab. 1), the mean winter DIP concentration show a slow decline of only $5 \%$ and $10 \%$ in the $50 \%$ reduction and $70 \%$ reduction runs, respectively. The likely cause is the continuous nutrient exchange with adjacent regions, as described above. This exchange also results in small changes in the chlorophyll concentration of about $5 \%$ in the $50 \%$ reduction and $7 \%$ in the $70 \%$ reduction.

\subsubsection{United Kingdom - UK-C1}

Target area UK-C1 is situated in UK coastal waters in the Southern Bight of the North Sea. Channel waters enter the area from the south, and meet North Sea coastal waters from the north. The river Thames and various smaller rivers discharge seasonally varying amounts of freshwater and nutrients into the area. Salinities are above 34.5 in the offshore parts of the area, but are lower closer to the coast and within estuaries, and salinities near the coast are lower in winter than in summer (Lee and Ramster, 1981). The $M_{2}$ tidal range varies from about $0.5 \mathrm{~m}$ in the north eastern corner to over $4 \mathrm{~m}$ in the upper reaches of the Thames estuary (Prandle, 1980), and tidal current velocities reach about $1 \mathrm{~m} / \mathrm{s}$. Devlin et al. (2008) found average SPM concentrations for UK southern east coast of around $18 \mathrm{mg} / \mathrm{l}$ while Mills et al. (1994) reported values ranging from 2.9 to $5.7 \mathrm{mg} / \mathrm{l}$ for the summer and winter respectively at an offshore location in the UK-C1 box. SPM in this region originates mainly from coastal erosion, with a minor contribution by the rivers. Devlin et al. (2008) have shown that SPM is the best single explanatory variable for the vertical attenuation coefficient $\left(k_{D}\right)$ for downwelling irradiance (PAR) for these waters with typical $k_{D}$ values around $1 \mathrm{~m}^{-1}$. In comparison to the less turbid waters of the summer-stratified North Sea, Mills et al. (1994) found that higher values of $k_{D}$ coupled with strong vertical mixing extended the period of light limitation for these waters, resulting in a delay in the onset of the spring bloom. Following the 2002 application of the OSPAR Comprehensive Procedure, the area was classified as a NPA.

Despite this NPA classification of UK-C1 most of the model results are above the OSPAR threshold for the mean winter DIN and DIP concentration. In contrast, all model results fall well below the threshold for the mean summer chlorophyll concentration at the surface. For the mean winter DIN concentration the models start with a large range of values for the hindcast above the threshold $(10.8 \mu \mathrm{mol} \mathrm{N} / \mathrm{l})$, from the DE model with $10.9 \mu \mathrm{mol} \mathrm{N} / \mathrm{l}$ up to $25.45 \mu \mathrm{mol} \mathrm{N} / \mathrm{I}$ in the BE model. All models show a linear decline in the DIN concentration, with the DE and the UK-Cefas model falling below the threshold in the $50 \%$ reduction run, while the NL and the UK-POL model pass the threshold in the $70 \%$ reduction. Only the FR and $B E$ models remains above the threshold for all simulations, but results of the BE model could be significantly influenced by the close proximity of their model boundary to this area.

Since the region is influenced by the river Thames and various smaller rivers and the reduction scenarios for the UK both include the reduction of DIP (Tab.1), the mean winter DIP concentration reflects the decline in the DIP concentration related to the reduction very well. Starting from values of $0.8 \mu \mathrm{mol} P / /$ for the DE and the FR models to $0.96 \mu \mathrm{mol} P / /$ for the UK-POL model, all these simulation results fall below the threshold for the $50 \%$ reduction run. With higher starting values in the mean winter DIP concentration the NL and BE model do not reach the threshold even in the $70 \%$ reduction scenario, whereas the UKCefas model predicts values below the threshold for all three scenarios. 
In contrast to the above threshold mean winter DIN and DIP concentration, all models give mean summer chlorophyll concentrations at the surface significantly below the threshold level of $15 \mu \mathrm{g} \mathrm{Chl} / \mathrm{l}$. While most concentrations range between 1.1 to $2.8 \mu \mathrm{g} \mathrm{Chl} / \mathrm{l}$, the NL model result is higher with $7.04 \mu \mathrm{g} \mathrm{Chl/l}$, but still less than half the threshold level. The NL model shows greater responsiveness to the reduction with a $23 \%$ fall in chlorophyll concentration in the $50 \%$ reduction and a $35 \%$ fall in the $70 \%$ reduction. This strong response is only exceeded by the BE model with a $45 \%$ and $60 \%$ decline for the reduction scenarios, although starting from much lower summer chlorophyll concentrations in the hindcast run.

\subsection{Model Spin Up}

The proposed procedure described above is based on the assumption that the inter-annual variability is low, so that a repeated integration of one year will give a realistic initial field for the following year. This is not necessarily true, and 2002 seems to be a year where this assumption does not hold.

(Fig. 8: about here)

The example from a long-term run with the NORWECOM model shows that spinning-up with a certain year, e.g. with high nutrient loads, can result in a high level of nutrients in a certain region (Skogen \& Mathisen, 2009). In Fig. 8a time series of the winter nutrients for G-C1 are given. There is a clear trend towards lower winter nutrient levels, but with a strong interannual variability. With a repeated integration of 2002 the models will converge towards winter 2003 values that are almost 50 and $30 \%$ higher than winter 2002 values for DIP and DIN, respectively. Such a spin-up, where the system is loaded with nutrients, will clearly yield different results compared to a simulation with either a repeated integration of 2001 , or a long-term run. Comparing the time series for the target area G-C1 (Fig. 8a) with the one for $\mathrm{NL}-\mathrm{C} 2$ (Fig. 8b), it appears that the described phenomenon is a local one, since the time series for the NL-C2 area follows a downward trend both for winter DIN and DIP values.

\subsection{Oxygen Deficiency}

In Fig. 9 the annual cycle of bottom oxygen concentration from the 2002 hindcast (Fig. 9a) and the $50 \%$ reduction scenario (Fig. 9b) simulated by the DE, UK-Cefas and NL models are presented for sample location Terschelling $135\left(54.4^{\circ} \mathrm{N}\right.$, to $4.04^{\circ} \mathrm{E}$; see Fig. 6). All these simulations follow a similar seasonal pattern, with an increase in the concentration early in the year, a strong decrease during summer and recovery of the oxygen concentration during autumn. In terms of the seasonal cycle the model results show a good agreement with the measured oxygen concentrations for 2002 at Terschelling 135 (Fig. 9a). In addition to the 2002 observations, the monthly averages over the period 1988-2003 together with their standard deviations are shown. According to the averaged year, based on the 15 years of oxygen data at this station, at the end of the summer the dissolved oxygen can indeed, in some years, fall below $6 \mathrm{mg} \mathrm{O}_{2} / \mathrm{l}$.

\section{(Fig. 9: $\quad$ about here)}


The DE and the NL simulations yield similar concentrations at the beginning of the year, close to the observations. During summer the NL simulation is on the high side of observed values, while the DE is more often found on the low side of observed values. The UK-Cefas starts with a lower concentration of $8.5 \mathrm{mg} \mathrm{O} / \mathrm{l}$ and has also lower values over the summer. Both the DE and the UK-Cefas models reach minimum values below the OSPAR threshold of $6 \mathrm{mg} \mathrm{O}_{2} / \mathrm{l}$, which defines oxygen depletion in the bottom water. Simulated oxygen depletion persists for 11 days in the DE simulation and for 22 days in the UK-Cefas results. Here the times of oxygen concentration below $6 \mathrm{mg} \mathrm{O}_{2} / \mathrm{l}$ are related to one day (21. Aug.), which matches exactly with the onset of the oxygen depletion period as simulated by the DE model, and a longer time interval later, which occurs slightly after the DE model oxygen depletion period. In contrast, the simulated oxygen concentration by the NL model did not fall below the $6 \mathrm{mg} \mathrm{O}_{2} / \mathrm{l}$ threshold.

The simulated bottom oxygen concentrations in the $50 \%$ reduction scenario (Fig. 9b) exhibit no period of oxygen depletion. This is a result of the reduced river loads and the corresponding lower organic load that reaches the bottom. Only the oxygen concentration from the DE simulation comes close to the threshold for a short period in summer. All simulations start from about the same level in winter, but do not reach the same low level of oxygen concentration in summer.

\section{Discussion}

In this study models have been used to simulate the eutrophication status of specific regions (target areas) of the North Sea and English Channel in response to reduction in the riverine nutrients as set out in the OSPAR convention. In order to evaluate the effectiveness of the approach it is necessary to consider what processes need to be incorporated to simulate and diagnose the anthropogenic process of eutrophication. This section identifies some of the processes that models need to represent, and discusses the range of approaches adopted and the degree of complexity required with reference to the models used.

According to the OSPAR definition eutrophication can be seen as falling into four stages:

(1) nutrient enrichment where addition is at a rate sufficient to overcome dilution or losses such as denitrification and leading to potential enhancement of local concentrations; accelerated growth of phytoplankton leading to the accumulation of extra biomass resulting from this growth;

(3) undesirable disturbance to the balance of organisms;

(4) changes to water quality.

Models must simulate key features of the physical environment as well as relevant chemical and biological processes. All the models applied used a three-dimensional approach (see Appendix A), providing a "realistic" simulation of the complex physical environment. The degree of complexity in the chemical and biological models also needs to be considered. Here the main problem is that of finding reliable values for parameters; the number of which increases, generally over-proportionally, with the number of state variables. All the biogeochemical models applied may be regarded as complex providing the potential to 
simulate most if not all of the key processes in anthropogenic eutrophication identified above. Except in cases where denitrification is a dominant process, requiring chemically complex models for its description (Middelburg et al., 1996), stage one of eutrophication is comparatively easy to simulate. The simplest approach balances nutrient inputs against dispersion losses from a box. Such a model, used to assess 'Equilibrium Concentration Enhancement' (ECE) of nutrients (Gillibrand and Turrell, 1997), has proven useful for identifying Scottish sea-lochs most at risk from fish-farm nutrients.

Generally, a good 3D physical model is required as a framework for applying a biological model. Skogen and Moll (2005) showed that the choice of the physical model is decisive in determining the response of a coupled ecosystem model. In their review on hydrodynamical models Lenhart and Pohlman (2004) referred to a number of studies, where the performance of a biological model is strongly dependent on the performance of the underlying physical model. These authors also stress the need for reliable data on boundary conditions. Obtaining such information, for example, on riverine inputs of freshwater and of dissolved and particulate nutrients is a non-trivial task and should be recognised as a potential limitation to the reliability of coupled physical-biological models used in relation to eutrophication.

Stage two concerns the conversion of nutrients into biomass and therefore requires biogeochemical models. All of the models used in the present study can be regarded as having a complex biogeochemistry with 12 to 51 pelagic state variables (see Appendix A). They simulate the yield of phytoplankton biomass from nutrients, using either a fixed, phytoplankton-group specific, or variable (Lancelot et al., 2005; Los and Wijsman, 2007) carbon to chlorophyll ratio.

Simulation of stage three (undesirable disturbance) requires the potential to simulate changes in the ecosystem structure. With regard to eutrophication this is typically interpreted as a change in the phytoplankton species composition. At its most simple, this is regarded as an increase in either the concentration of flagellates, mostly Phaeocystis species, or an increase in the relative fraction of flagellate biomass in total phytoplankton biomass (Breton et al., 2006). Only complex biogeochemical models are able to simulate this stage of eutrophication. The best-known example of a complex ecosystem model is the European Regional Seas Ecosystem Model (ERSEM), which in its version II (Baretta-Bekker et al., 1997) emulates a system containing diatoms, dinoflagellates, autotrophic flagellates, "picoalgae", heterotrophic nanoflagellates, bacteria, microzooplankton and mesozooplankton. It has been successfully used by Pätsch \& Radach (1997), with dinoflagellates replaced by Phaeocystis, to simulate changes in the diatom-flagellate balance induced by anthropogenic nutrient enrichment of the southern North Sea. Proctor et al. (2003) have embedded ERSEM in a highly-resolved 3-D circulation model of the North Sea in order to calculate nutrient fluxes between different parts of the north-western European continental shelf. More recently, Vichi et al. (2007) embedded the BFM model (a successor to ERSEM) into a global ocean circulation model. ERSEM is also used in operational forecasting (Siddorn et al., 2007).

All the models applied here use the functional group approach (FG), with each FG being a bulk parameterisation of a community of typical flagellates, diatoms, etc. typifying a normally heterogeneous mixture. However, some models besides including FGs also incorporate parameterisations for different stages of e.g. Phaeocystis (MIRO\&CO-3D/BE model) and the harmful alga Karenia mikimotoi (ECO-MARS3D/FR model). The behaviour of FGs and specific phytoplankton species can be important for the balance between organisms and therefore in assessing the undesirable disturbance. As an example, diatoms are non-motile 
and sink, while flagellates can move small distances vertically. This difference can be expressed in models with a refined vertical description in order to better describe the vertical distribution of specific plankton and their access to light and nutrient resources.

The complexity of ecosystem models within a 3-D hydrodynamic framework was studied by Moll and Radach (2003). They identified eleven three-dimensional coupled physicalbiological models for the North Sea, seven of which were reviewed in more detail in terms of spatial and temporal resolution, degree of trophic complexity and the processes relating state variables to each other. They concluded that these 3-D ecological models of the greater North Sea (NORWECOM, GHER, ECOHAM, ERSEM, ELISE, COHERENS and POL3dERSEM) provided consistent dynamics of the lower trophic levels on regional, annual and decadal scales. The results from these model simulations either confirmed existing knowledge derived from field work or gave new insight into the ecosystem structure and function. Model simulations have contributed to improve our knowledge of the temporal and spatial development and magnitude of primary production, its limitations, the mechanisms of nutrient regeneration, the effects of riverine and atmospheric nutrient inputs in causing eutrophication of coastal waters, and nutrient budgets. Allen et al. (2004) (applying the POL3dERSEM within the MERSEA project) showed the need to improve the representation of the underwater light climate in shallow $(<20 \mathrm{~m})$ coastal waters in order to better simulate the light-dependent growth of phytoplankton and thereby its response to changes in nutrient input. As the light climate in these waters is largely determined by suspended matter concentration, the representation of the deposition and resuspension processes needs to be improved.

Stage four concerns changes in water quality. Regarding eutrophication in the sea, an indicative parameter for water quality is the dissolved oxygen concentration. Most marine policies aim at an oxygen concentration higher than $4 \mathrm{mg} \mathrm{O}_{2} / \mathrm{l}$, or $6 \mathrm{mg} \mathrm{O}_{2} / \mathrm{l}$ in the OSPAR CP as applied in this assessment, because organisms from higher trophic levels may suffer from prolonged hypoxic conditions. The prediction in time and space of changes in oxygen concentration is not a trivial issue and requires generally state-of-the-art eco-hydrodynamical modelling, especially in stratified water columns.

\subsection{Workshop Set-up}

In order to improve comparability of model results in the nutrient reduction scenarios three requirements were specified. These were a minimum spinning-up of three years, the use of consistent boundary conditions and of identical forcing data.

Because the previous modelling work in the North Sea identified the boundary conditions as a source of variability between model results (OSPAR, 2008a), a considerable effort was made to provide a common set of boundary condition for the different models. Since it was not feasible to generate the necessary data from measurements, the boundary data were provided by the Atlantic Margin Model POLCOMS-ERSEM (UK-POL) for each of the different national models (Fig.2) for the standard run and the two reduction scenarios. The aim was to provide the boundary conditions from a consistent representation of the ecological state of the North Sea. This was important especially for the models with smaller model domains, where the influence of river load reductions outside their actual model domain needs to be considered. In general, the use of common boundary conditions in this study has considerably reduced the differences between models results. 
In addition, the spin-up procedure using the year 2002 was regarded as suitable for reaching a quasi-equilibrium between external forcing and internal dynamics and providing a reliable basis for the simulation. Prolonging the spin-up for a series of years would achieve a further robustness by including inter-annual variability. The experience gained from the long-term run with NORWECOM shows that spinning-up with a specific year, e.g. with high nutrient loads, can result in a high level of nutrients in a certain region. This reflects a general problem of the spin-up procedure, however, since all the models in the present study achieved their equilibrium by the recommended procedure, the differences in the model results due to different numbers of spin-up years are expected to be only of minor relevance.

When carrying out a study on riverine nutrient load reduction, it is most important to have reliable data on the river loads. These data have for the first time been collected with nearly complete coverage for the North Sea and at high (daily) resolution. This is a major improvement compared to the ASMO workshop (Villars and De Vries, 1998) on eutrophication modelling where riverine load data were only available on a monthly basis, for just the main rivers.

In order to carry out realistic reduction scenarios for 2002 it was necessary to calculate the additional percentage reduction in relation to 1985 levels for nitrogen and phosphorus. This calculation was needed in order to determine what actual reduction was required in order to achieve a $50 \%$ and $70 \%$ reduction for each country (Tab. 1). The disadvantage arising from this specific reduction setup as required by OSPAR is that the results can not be compared with previous studies, where an equal reduction of phosphorus and nitrogen loads was applied across all countries as was the case in the ASMO workshop (Villars and De Vries, 1998) or studies by Lenhart (2001), Lacroix et al. (2007), Lancelot et al. (2008) and Skogen and Mathisen, (2009). The reason for taking into account the reductions already achieved by contracting parties when constructing the realistic scenarios was that the results from this study can be used in guiding contracting parties in any remediation they carry out to meet OSPAR requirements. For example, on the basis of model results contracting parties may decide on what level of riverine nutrient reduction they wish to achieve in order to change the eutrophication status of their marine waters.

\subsection{Net Primary Production}

Besides the conceptual differences detailed in 4.1, one can expect that the horizontal heterogeneity of NPP reflects the horizontal gradients of its limiting factors. The North Sea, and especially the coastal areas, exhibit significant spatial gradients in nutrients and light, both limiting growth and NPP. Light availability is strongly influenced by SPM concentrations and by bathymetry. The vertically-integrated NPP varies with the mixing depth, which controls the losses due to autotrophic respiration. Since all models have similar bathymetries, the large-scale response of NPP to horizontal depth gradients is similar (i.e. higher NPP in shallow areas, and vice versa). This is supported by measurements, e.g. by Joint and Pomroy (1993) obtained as part of the UK NERC North Sea Project. While the Dogger Bank, as an isolated topographical feature, gave NPP values regarded as too high in their interpolation routine (Joint, pers. comm.), the overall gradient with higher NPP values in the shallow coastal areas is apparent.

The differences in NPP onshore-offshore gradients between models are due to differences in gradients of nutrients or light availability, with the latter mainly determined by the SPM background concentration applied in the model. From this perspective NPP estimates also depend significantly on the grid resolution, which can be seen in the more heterogeneous 
('patchy') horizontal picture of net primary production produced by models with smaller domains, e.g. in the MIRO\&CO-3D (BE) model.

\subsection{Difference between Standard run and the $50 \%$ reduction scenario}

Despite the differences in the definition of the NPP, all large-domain models, except the GETM-BFM (UK-Cefas) model, identify an area of maximum reduction in the NPP stretching from the northern coast of Denmark toward the Humber and Thames estuaries. In essence this means that the highest differences in the resulting NPP between the hindcast simulation and the $50 \%$ reduction scenario are seen in (near) offshore waters.

The decrease in nutrient concentrations after a load reduction is not always followed by a decrease in net phytoplankton production. This can be explained by comparing the nutrient concentrations to the factors limiting NPP, which depend on the location or on the moment. Though the assessment of the limiting factors is not a trivial task, some numerical models (Los and Wijsman, 2007) and conceptual models (Loebl et al., 2009) are able to provide spatial and temporal estimates. To facilitate the present interpretation, we only examine the spatial gradients of the annual mean results.

Results from the GEM (NL) model (present exercise, not shown; see also Blaas et al., 2007) indicate a succession of limiting factors from the coastal zone to the offshore area. In the coastal zones, NPP is mostly either light- or phosphorus-limited, except off the Danish coast and in the plumes of the Thames and Humber rivers. However, the load reduction mainly results in a decrease in nitrogen concentrations. This explains the general low response of the modelled NPP along the coast. Yet, along the northern Danish coastal area and in the plumes of UK rivers, where the nitrogen reduction results in a nitrogen-limitation of the production, NPP decreases significantly. The BE model shows high sensitivity of NPP to nitrogen reduction in the Belgian coastal waters. In this area phytoplankton blooms are dominated by Phaeocystis, characterised by very low affinity to phosphorus (Lancelot et al., 2007); thus they are more sensitive to nitrogen than phosphorus reduction. The relative decrease in nitrogen concentration due to the river load reduction is generally less significant offshore than in the coastal zone because in the offshore, river water fractions are lower. Therefore, the modelled NPP in offshore waters, though mainly limited by nitrogen and silica (except for the Channel area which is light-limited), does not decrease significantly. This is especially the case for the central North Sea. An effect on offshore NPP is nevertheless observed in the model results, especially in the "corridor" reaching from south England and Belgium towards Denmark.

An assessment of the results of the GETM-BFM (UK-Cefas) model expressed as degree of limitation of $\mathrm{N}$ and $\mathrm{P}$ indicated that in summer, phytoplankton growth in the entire North Sea was limited by the availability of both nutrients. In winter, a degree of both $\mathrm{N}$ and $\mathrm{P}$ limitation persisted in the Southern Bight and the English Channel. Throughout, $\mathrm{P}$ was in slightly shorter supply than $\mathrm{N}$. These examples indicate the necessity to develop a common framework for the analysis of model results in terms of limiting factors, which finally also could help to interpret in-situ measurements, e.g. for the forthcoming OSPAR assessment.

\subsection{Target area assessment}


The workshop results provide insight into the response of selected eutrophication assessment parameters to the reduction of nutrient loads. The model results are presented and scored against area-specific assessment levels applied in the first application of the Comprehensive Procedure in 2002. However, while the model results should be regarded as indicating the direction of changes in levels and effects, they do not exactly predict the eutrophication status in the marine environment with respect to nutrient enrichment.

The presentation of the individual target areas demonstrated that the assessment for each region is related to the local characteristics, e.g. the water exchange. Generally, the largest reductions are seen in the simulated DIN concentration for coastal water target areas. The model results show a strong, nearly linear response in winter DIN concentration to the load reduction. Winter DIP shows an equally strong response in the UK-C1 target area, the only coastal area to experience a direct reduction in $\mathrm{P}$ loads as the French, Dutch and German rivers do not reduce $\mathrm{P}$ under the $50 \%$ scenario (having already achieved this reduction between 1985 and 2002). Offshore, the response is less pronounced, especially for DIP, with most models only responding when continental riverine $\mathrm{P}$ loads are reduced under the $70 \%$ reduction scenario. Hence, the difference in net phytoplankton production is negligible in $\mathrm{P}$ limited areas under the $50 \%$ reduction scenario.

The overall range of response in mean summer chlorophyll concentrations at the surface is from $11 \%$ to $36 \%$ and is similar both for offshore and coastal areas, with the highest decrease in the coastal waters in the $50 \%$ reduction runs. Generally this parameter is not highly responsive to reduced nutrient loads.

The comparison with the simulated values indicates that the threshold values are not always consistent. For example, the box F-C2 has the highest DIP threshold value $(1.2 \mu \mathrm{mol} P / \mathrm{l})$ of all boxes, while the DIP threshold for the nearby NL-C2 target area is $0.8 \mu \mathrm{mol} P / \mathrm{I}$. In contrast, the DIN threshold value for F-C2 is $10.8 \mu \mathrm{mol} \mathrm{N} / \mathrm{l}$, which is half the value for NL-C2 $(30 \mu \mathrm{mol} \mathrm{N} / \mathrm{l})$. The threshold value for chlorophyll in F-C2 is $4 \mu \mathrm{g} \mathrm{Chl} / \mathrm{l}$ and $15 \mu \mathrm{g} \mathrm{Chl} / \mathrm{l}$ in NLC2.

\subsection{Oxygen concentration}

In contrast to the OSPAR criteria used in the assessment so far, the bottom oxygen concentration averaged over a target area was not considered as a meaningful result. Therefore, the oxygen concentrations from the hindcast runs were compared with data from the Dutch station Terschelling 135, where measurements were available which resolve the seasonal cycle (Fig. 9a). It should be noted that the position Terschelling 135 is located within the target area NL-O2, which suffers from oxygen depletion towards the end of summer (see target area description, see 4.3.5). Generally, the modelled oxygen concentration matches the measurements very well. It is not clear if the measurements in 2002 simply miss the oxygen depletion period, or if there was no oxygen depletion below 6 $\mathrm{mg} \mathrm{O}_{2} / \mathrm{l}$ that year. However, the inter-annual variability of the observations (characterised by the standard deviation in Fig. 9a) indicates that, in some years, critically low oxygen concentrations are reached at the end of summer. The three simulation results shown in Fig. $9 \mathrm{a}$ bracket the range of the observations. Two out of three models predict an exceedance of the low oxygen threshold level for later summer periods of 10 to 20 days. The third model exhibits results on the high side of possible values. One might conclude that between-model uncertainty is as large as the inter-annual variability. In other words, it is still a challenge for the modelling community to achieve a stage where the average of the model results has more skill than the application of observation-derived climatology to assess the probability of oxygen deficiency in a particular year. Nevertheless, the model simulations still provide a more detailed description in time than the field observations, and also possibly insight into 
the processes responsible for oxygen variations. In that sense, modelling can help to interpret the measurement-based assessments. One further step in the support by model simulations in gaining interpretation capability for measurements would be to add a spatial component to the assessment, e.g. by providing plots of the extension of the area where oxygen depletion occurs.

\subsection{Impact of a nutrient reduction}

The Southern Bight of the North Sea and the Wadden Sea have been subjected to nutrient enrichment since the 1960's, followed by a subsequent nutrient reduction since the late 1980's. The impact of these changes on the coastal and marine ecosystems of the North Sea is far from being identified, let alone understood. The present study contributes to point out the complex interplay between nutrient availability and primary production. The modelled phytoplankton production (annual mean result) does not always respond in proportion to the imposed nutrient reduction because of the geographical contrast between reduced-nutrient areas and nutrient-limited areas. For instance, if a nitrogen reduction occurs in an area where the primary production is initially light-limited, the effect of the reduction on NPP will remain marginal, unless the nitrogen reduction becomes so important as to induce a change in limiting factors for dominant species. Such a switch in limiting factors happens over space and time in a system as a function of changes in external drivers (i.e. loads, seasonal forcing, anomalies, ...). It also depends on the phytoplankton species composition and succession, which is sometimes controlled by internal food-web processes.

Previous modelling work and mesocosm experiments in the Dutch coastal zone pointed as well to a limited impact of a nutrient reduction on phytoplankton production and biomass (De Vries et al., 1998). Some studies report significant correlations between coastal nutrient enrichment or reduction and changes in the species composition. A monitoring program, started in 1990, shows that the phytoplankton composition in the Dutch continental shelf has changed significantly with increasing proportions of diatoms and dinoflagellates; yet, the annual mean carbon biomass over all monitoring stations remained stable (Baretta-Bekker et al., 2009). During the eutrophication phase, over the period 1974-85, an increase in the bloom duration and the abundance of Phaeocystis was observed in the southern North Sea, causing variations in the Phaeocystis:diatom ratio in spring (Jickells, 1998). In the Wadden Sea, the long-term variation in limiting nutrients $(\mathrm{P}, \mathrm{Si})$ is weakly correlated with biomass and more strongly with variations in the community structure, involving phytoplankton, macrozoobenthos and estuarine birds (Philippart et al., 2007). Despite the likely correlations, a direct relationship between trends in nutrient loading and ecosystem changes has not yet been established in the North Sea. In contrast to lakes, some coastal systems exhibit a lack of coherent phytoplankton response to nutrient reduction; and physicochemical factors, such as temperature, light and nutrients, do not alone explain the changes in species composition or the trends in phytoplankton biomass (Smetacek and Cloern, 2008). Significant trends or shifts in phytoplankton species composition may also result from climate oscillations, from oceanographic anomalies (Edwards et al., 2002), or from a change in top-down control by the grazers (Jassby et al., 2002). This suggests that in dynamic systems such as the North Sea, the impact of a nutrient enrichment or reduction may be masked by other mechanisms. Besides, long-term changes in nutrient input could also trigger profound changes across trophic levels of coastal communities, increasing even more the unpredictability of the ecosystem response (Philippart et al., 2007). The implementation of such processes in ecohydrodynamic modelling may contribute to improve the system understanding, though at the cost of an increasing model complexity. 


\section{Conclusions}

Multiple effects are difficult to distinguish in field data and it is the power of models to distinguish between multiple effects, which make them very good tools to carry out (numerical) experiments on the effects of nutrient reduction. The OSPAR ICG-EMO workshop was organised in order to compare the response of a number of North Sea eutrophication models to nutrient reduction scenarios. Special attention was given to the derivation of river loads for the reduction scenarios in relation to the reductions achieved by the different countries between 1985 and 2002. In a first step the horizontal distributions of the net primary production (NPP) obtained by different models in the 2002 hindcast run were compared, as well as the response to the $50 \%$ reduction given as difference to the hindcast. Then the hindcast and the reduction runs were compared for selected target areas and scored against the Comprehensive Procedure assessment levels for the parameters DIN, DIP and chlorophyll. Finally, the temporal development for the assessment parameter bottom oxygen concentration was discussed.

The workshop concluded that models can be usefully applied to support the application of the OSPAR Comprehensive Procedure. Models can be used in a variety of ways to directly support the assessment process, for example, through extrapolation to provide model results on the levels of assessment variables. Models can give indirect support by exploring the behaviour of indicators under various condition or be used to identify potentially new indicators of eutrophication. A novel aspect of the nutrient reduction scenario tests reported at the workshop was the reconstruction of the Comprehensive Procedure using model results for assessment variable levels. A comparative exercise formulated specifically for the workshop required models to be run for pre-defined target areas previously classified as Problem Areas following the first application of the Comprehensive Procedure. The responsiveness of the modelled assessment parameters varied between different models but in general a larger response in coastal rather than in offshore water bodies was obtained. Further work was identified and proposed as a result of the workshop to confirm and bolster confidence in the results.

A general difficulty appeared to be the model forcing with SPM data in order to achieve realistic simulation of light attenuation, especially in the coastal region. In these shallow waters turbidity is generally higher and light conditions less favourable for algae growth. Future work could benefit from a shared effort in generating SPM fields either through the use of remote sensing and in situ measurements or by the use of SPM model routines. In any case progress is needed for the application of ecosystem models in coastal areas, since SPM is the most important explanatory variable for light attenuation in these models.

In addition to a better SPM representation, there is a need for a better assessment of the factors limiting NPP. This plays a key role in the understanding of the effect of river load reduction to the coastal system. When estimating the effect of nutrient reduction on NPP, the knowledge of the limiting factors has proven useful to understand the complexity of the phytoplankton response. In turn, chlorophyll $a$, as a resulting parameter allows suggestions about the consequences for higher trophic levels.

The example of the NORWECOM long-term run offers insight to the way we should look at the spin-up procedure in terms of achieving a steady state. For example, when 2002 is the year of interest, it might be best to have a spin-up e.g. on the year 1995 to reach some equilibrium and then have a continuous simulation towards 2002 including all the year-toyear variability. 
Biotic and abiotic processes in sediments have both direct and indirect impacts on the availability of nutrients in the water column and the memory of the system. The extent to which benthic processes are included in the models used in this study varies considerably. Most use a simple 'benthic return' approach, but the MIRO\&CO-3D (BE) model incorporates more complex diagenetic equations. The GETM-BFM (UK-Cefas) has an extensive benthic model (most recently described in the PhD-thesis of M.Vichi, for details see: http://docserver.bis.uni-oldenburg.de/publikationen/dissertation/2002/vicpre02/vicpre02.html) that incorporates abiotic processes, an explicit benthos including filter feeders as well as benthic nutrients. The POLCOMS-ERSEM (UK-POL) model includes nutrient and carbon cycling through the benthic food web and transfer of particulate organic matter between the pelagic and benthic systems. The extent to which each model system may store nutrients from 1 year to the next (i.e. system memory) depends largely on the presence/absence of refractory components in the benthic model. At their most simple no memory will be present but for more complex benthic models memory may persist for a number of years.

A debate regarding the most appropriate method for validation continues. This issue is addressed in the discussions at the Workshop on Future Directions on Physical-Biological Interactions held under the auspices of ICES since 2004. Of particular relevance to eutrophication modelling is the choice of state variables to be compared with observations. Although most ecosystem models represent phytoplankton biomass in carbon units they deliver chlorophyll concentration as a proxy for phytoplankton biomass and validate the model against Chl-a observations. These values are typically derived using fixed carbon:chlorophyll ratios, whereas this ratio is variable in nature. This introduces uncertainty into the validation procedure. A better approach may be to choose system-level quantities that are not subject to such uncertainties such as SPM, $\mathrm{O}_{2}$ and nutrient concentrations. These state variables have the advantage of being directly measurable quantities, unlike phytoplankton carbon. Additionally, modelled and observed concentration profiles could be compared, providing important information on vertical dynamics. Oxygen is a key variable in conveying information about system response to nutrient inputs as well as an indirect indicator of eutrophication. Trends in oxygen concentration will supply information on the relative importance of auto- and heterotrophy and hence the likely response to nutrient inputs. There is also a strong case for comparing modelled rates, such as primary production, with field data. The implication of such approaches to model validation is that the choice of variables to be monitored may have to be adjusted to ensure that future model applications are well-tested, robust and reliable.

The availability of sufficient river nutrient input data is of critical importance for realistic hindcasts of ambient nutrient concentration and the consequent response of the ecosystem. While Pätsch and Lenhart (2004) have made available 25 years of daily nutrient loads (ftp://ftp.ifm.uni-hamburg.de/pub/data/riverload/), a similar effort is required for the other rivers entering the North Sea. Such an effort will need to be organised nationally via the appropriate agencies tasked with monitoring riverine data. A minimum requirement is for monthly resolved nutrient input data.

\subsection{Supporting policy needs through the use of models}

Where models are used to support policy implementation (e.g. assessment of eutrophication) or policy development there is a fundamental requirement for robustness and reliability. As a result the attributes of the model(s) to be applied must be clearly defined and there needs to be clarity about the way in which the model(s) will be used. A useful distinction is between models used as 'engineering tools' or as tools for testing hypotheses. In the first instance the answers must be reliable and stand up to scrutiny. This use is distinct from the latter scientific use where numerical models are designed to improve understanding by testing 
hypotheses. A requirement for models used as engineering tools means that they are not only robust and reliable but also transparent and easily understood with the implication that they are likely to be simplistic. However, the debate regarding the necessary complexity identifies a difference in philosophies within the scientific community that needs to be explored further. The way forward is likely to embrace both sides of the argument by identifying where in the system to be modelled complexity is required and where simplicity will suffice. The motto should be: As simple as possible and as complex as necessary.

\section{Acknowledgement}

The ICG-EMO organising group wants to thank Andrea Weiss from the OSPAR Secretariat for her persistent help over the last years.

The authors from the IfM Hamburg want to thank their colleagues Johannes Pätsch, Andreas Moll, Christoph Stegert and Larissa Müller for their contributions as well as Christian Lindemann and Huadong Liu for technical support.

The authors gratefully acknowledge the ECMWF (European Centre for Medium Range Weather Forecasting) for allowing use of the meteorological data, and EMEP (European Monitoring and Evaluation Programme) for making the atmospheric deposition data available. The authors also thank all contributors to the OSPAR daily riverine loads database. French water quality data were supplied by the Agence de l'eau Loire-Bretagne, Agence de l'eau Seine-Normandie and IFREMER. UK water quality data were processed from raw data provided by the Environment Agency, the Scottish Environment Protection Agency and the National River Flow Archive. The German river loads are based on data from the ARGE Elbe, the Niedersächsisches Landesamt für Ökologie and the Bundesanstalt für Gewässerkunde. The river load data for the Netherlands were supplied by the DONAR database.

\section{References}

Allen, J.I., Blackford, J., Holt, J., Proctor, R., Ashworth, M., Siddorn, J., 2001. A highly spatially resolved ecosystem model for the North West European Continental Shelf. Sarsia, $86,423-440$.

Allen, J.I., Gilbert, F.J., Holt, J.T., Holt, M., Mills, D.K., Proctor, R., Siddorn, J.R, 2004. Eutrophication modelling in the North Sea. Final Report EU Project; MERSEA strand 1.

Aminot, A., Guillaud J.-F., Kérouel R., 1997. La baie de Seine: hydrologie, nutriments et chlorophylle (1978-1994). Ed. Ifremer, Repères Océan, 14, 148 pp.

Baretta, J.W., Ebenhöh, W., Ruardij, P., 1995. "The European Regional Seas Ecosystem Model, a complex marine ecosystem model", Journal of Sea Research, 33, 233-246.

Baretta-Bekker, J.G., Baretta, J.W. (Eds), 1997. European Regional Seas Ecosystem model II, Journal of Sea Research 38, 169-436.

Baretta-Bekker, J.G., Baretta J.W., Latuhihin M.J., Desmit X., Prins T.C., 2009. Description of the long-term, 1991-2005) temporal and spatial distribution of phytoplankton carbon biomass in the Dutch North Sea. Journal of Sea Research 61, 50-59. doi: 10.1016/j.seares.2008.10.007 
Bell, M.J., Forbes, R.M., Hines, A., 2000. Assessment of the FOAM global data assimilation system for real time operational ocean forecasting. Journal of Marine Systems, 25, 1-22.

Billen, G., Dessery, S., Lancelot, C., Meybeck, M., 1989. Seasonal and interannual variations of nitrogen diagenesis in the sediments of a recently impounded basin. Biogeochemistry 8,73-100.

Blaas, M., Desmit X., Los F.J., 2007. OSPAR eutrophication modelling - workshop 2007 : application of the Southern North Sea GEM, Report Z4351, WL | Delft Hydraulics, Nov. 2007.

Blackford, J.C., Allen, J.I., Gilbert, F.J., 2004. Ecosystem dynamics at six contrasting sites: a generic modeling study. Journal of Marine Systems, 52, 191-215.

Blauw, A.N., Los, F.J., Bokhorst, M., Erftemeijer, P.L.A., 2009. GEM: a generic ecological model for estuaries and coastal waters. Hydrobiologia 618, 175-198. doi: 10.1007/s10750008-9575-x

Breton, E., Rousseau, V., Parent, J.-Y., Ozer, J., Lancelot, C., 2006. Hydroclimatic modulation of the diatom/Phaeocystis blooms in the nutrient-enriched Belgian coastal waters, North Sea. Limnology and Oceanography, 51(3), 1-14.

Brion, N., Jans, S., Chou, L., Rousseau, V., 2008. Nutrient loads to the Belgian Coastal Zone. In: V. Rousseau, C. Lancelot and D. Cox, Editors, Current status of Eutrophication in the Belgian Coastal Zone. Presses Universitaires de Bruxelles, pp. 17-43. [book downloadable at http://www.belspo.be/belspo/home/publ/pub_ostc/OA/OA14_en.pdf]

Burchard, H., Bolding, K., 2002. "GETM, a general estuarine transport model: scientific documentation" Technical Report no. EUR 20253 EN, European Commission, 157 pp.

Cadée, G.C., Hegeman, J., 2002. Phytoplankton in the Marsdiep at the end of the $20^{\text {th }}$ century; 30 years monitoring biomass, primary production and Phaeocystis blooms. J. Sea Res. 48: 97-110.

Claussen, U., Zevenboom, W., Brockmann U., Topcu, D., Bot P., 2009. Assessment of the eutrophication status of transitional, coastal and marine waters within OSPAR. Hydrobiologia, in press.

Cloern, J.E., 2001, Our evolving conceptual model of the coastal eutrophication problem, Marine Ecology Progress Series 210, 223-253.

Cugier, P., Billen G., Guillaud J.F., Garnier J., Ménesguen A., 2005. Modelling the eutrophication of the Seine Bight, France under historical, present and future riverine nutrient loading. Journal of Hydrology, Journal of Hydrology, 304, 381-396.

De Jonge, F., 2006, Marine Eutrophication in perspective, on the relevance of ecology for Environmental Policy, Springer, 335 pp.

De Vries, I., Duin, R.N.M., Peeters, J.C.H., Los, F.J., Bokhorst, M., Laane. R.W.P.M., 1998. 'Patterns and trends in nutrients and phytoplankton in Dutch coastal waters: comparison of time-series analysis, ecological model simulation and mesocosm experiments.' In ICES Journal of Marine Science, 55, 620-634.

Dethlefsen, V., Von Westernhagen, H., 1983. Oxygen deficiency and effects on bottom fauna in the eastern German Bight 1982. Meeresforschung 30: 42-53. 
Devlin, M.J., Barry, J., Mills, D.K., Gowen, R.J., Foden, J., Sivyer, D., Tett, P., 2008. Relationships between suspended particulate material, light attenuation and Secchi depth in UK marine waters. Estuarine, Coastal and Shelf Science 79, 429-439, doi: 10.1016/j.ecss.2008.04.024

Edwards, M., Beaugrand, G., Reid, P.C., Rowden, A.A., Jones, M.B., 2002. Ocean climate anomalies and the ecology of the North Sea. Marine Ecology Progress Series, 239, 1-10.

Eisma, D., Kalf, J., 1987. Dispersal, concentration and deposition of suspended matter in the North Sea, Journal of the Geological Society; 144, 161-178.

Gillibrand, P.A., Turrell, W.R., 1997. The use of simple models in the regulation of the impact of fish farms on water quality in Scottish sea lochs. Aquaculture, 159, 33-46.

Guillaud, J.F., Ménesguen A.,1998. Modélisation sur vingt ans, 1976-1995) de la production phytoplanctonique en Baie de Seine, France), Oceanol. Acta, 21(6), 887-906.

Heath, M.R., Edwards, A.C., Pätsch, J., Turell, W.R., 2002. Modelling the behaviour of nutrients in the coastal waters of Scotland. Fisheries Research Services Marine Laboratory Aberdeen, Scottish Executive Central Research Unit Contract, 106 pp.

Holt, J.T. and I. D. James, 2001. An s coordinate density evolving model of the north west European continental shelf. Part 1: Model description and density structure. Journal of Geophysical Research, 106(C7), 14015-14034.

Jassby, A.D., Cloern J.E., Cole B.E., 2002. Annual primary production: Patterns and mechanisms of change in a nutrient-rich tidal ecosystem. Limnol. Oceanogr. 47(3), 698-712.

Jickells, T.D., 1998. Nutrient Biogeochemistry of the Coastal Zone. Science, 281, 217-222.

Joint, I., Pomroy, A., 1993. Phytoplankton biomass and production in the southern North Sea. Marine Ecological Progress Series 99, 169-182.

Lacroix, G., Ruddick, K.G., Ozer, J., Lancelot, C., 2004. Modelling the impact of the Scheldt and Rhine/Meuse plumes on the salinity distribution in Belgian waters, southern North Sea. Journal of Sea Research, 52, 149-163.

Lacroix, G., Ruddick, K., Gypens, N., Lancelot, C., 2007. Modelling the relative impact of rivers, Scheldt/Rhine/Seine) and Channel water on the nutrient and diatoms/Phaeocystis distributions in Belgian waters, Southern North Sea). Continental Shelf Research, 27, 14221446. doi: 10.1016/j.csr.2007.01.013

Lancelot, C., Spitz, Y., Gypens, N., Ruddick, K., Becquevort, S., Rousseau, V., Lacroix, G., Billen, G., 2005. Modelling diatom and Phaeocystis blooms and nutrient cycles in the Southern Bight of the North Sea: the MIRO model. Marine Ecology Progress Series, 289, 6378.

Lancelot, C., Gypens, N., Billen, G., Garnier, J., Roubeix, V., 2007. Testing an integrated river-ocean mathematical tool for linking marine eutrophication to land use: The Phaeocystisdominated Belgian coastal zone, Southern North Sea) over the past 50 years. Journal of Marine Systems, 64(1-4), 216-228. doi:10.1016/j.jmarsys.2006.03.010

Lancelot, C., Lacroix, G., Gypens, N., Ruddick, K., 2008. Ecological modelling as a scientific tool for assessing eutrophication and mitigation strategies for Belgian coastal waters. In: $\mathrm{V}$. Rousseau, C. Lancelot and D. Cox, Editors), Current status of Eutrophication in the Belgian Coastal Zone. Presses Universitaires de Bruxelles, pp. 91-110. 
[book downloadable at http://www.belspo.be/belspo/home/publ/pub_ostc/OA/OA14_en.pdf]

Lazure, P., Dumas, F., 2008. A 3D hydrodynamical model for applications at regional scale (MARS3D). Application to the Bay of Biscay. Advance in water resources, 31, 233-250.

Lee, A.J., Ramster, J.W., 1981. Atlas of the seas around the British Isles. Ministry of Agriculture, Fisheries and Food, printed by Ordnance Survey, Southampton.

Lenhart, H.-J., 2001. Effects of River Nutrient Load Reduction on the Eutrophication of the North Sea, Simulated with the Ecosystem Model ERSEM. In: Kröncke I, Türkay M, Sündermann J, eds), Burning issues of North Sea ecology, Proceedings of the 14th international Senckenberg Conference North Sea 2000, Senckenbergiana marit. 31, 299311.

Lenhart, H.J., Pohlmann, T., 1997. The ICES box approach in relation to results of a North Sea circulation model. Tellus 49A, 139-160.

Lenhart, H.J. Pohlman, T., 2004. North Sea Hydrodynamic Modelling: a Review. Senckenbergiana maritima, 34, 1/2), 53-88.

Loebl, M., Colijn F., Van Beusekom J.E.E., Baretta-Bekker J.G., Lancelot C., Philippart C.J.M., Rousseau V., Wiltshire K.H., 2009. Recent patterns in potential phytoplankton limitation along the Northwest European continental coast. J. Sea Res. doi: 10.1016/j.seares.2008.10.002

Los, F.J., M. Blaas, this issue. Complexity, accuracy and practical applicability of different biogeochemical model versions. Submitted to J. Mar. Sys special issue AMEMR conference 2008.

Los, F.J., Bokhorst, M., 1997. Trend analysis Dutch coastal zone. In: New Challenges for North Sea Research. Zentrum for Meeres- und Klimaforschung, University of Hamburg, pp 161-175.

Los, F.J., Wijsman J.W.M., 2007. Application of a validated primary production model, BLOOM, as a screening tool for marine, coastal and transitional waters. J. Mar. Syst. 64, 201-215.

Los, F.J., M.T. Villars, M.W.M. Van der Tol, 2008. A 3- dimensional primary production model, BLOOM/GEM) and its applications to the, southern North Sea, coupled physicalchemical-ecological model). Journal of Marine Systems. doi:101016/j.jmarsys.2008.01.002

Luyten, P.J., Jones, J.E., Proctor, R., Tabor, A., Tett, P., Wild-Allen, K., 1999. COHERENS documentation: A coupled hydrodynamical-ecological model for regional and shelf seas: user documentation. MUMM internal document, Brussels, MUMM, 903 pp.

Ménesguen, A., Guillaud, J.-F., Hoch, T., 1995. Modelling the eutrophication process in a river plume: the Seine case study, France). Ophelia 42, 205-225.

Middelburg, J.J., Soertaert, K., Herman, P.J., Heip, C. H.R., 1996. Denitrification in marine sediments: a model study. Global Biogeochemical Cycles, 10, 661-673.

Mills, D.K., Tett, P.B., Novarino, G., 1994. The spring bloom in the South Western North Sea in 1989. Netherlands Journal of Sea Research, 33, 65-80. 
Moll, A. and Radach, G., 2003. Review of three-dimensional ecological modelling related to the North Sea shelf system Part 1: models and their results. Progress in Oceanography, 57, 175-217.

Müller, L., Pätsch, J., Kühn, W., in prep. Oxygen deficiency periods in the North Sea - a modelling study using ECOHAM.

Nechad, B., De Cauwer, V., Park, Y., Ruddick, K., 2003. Suspended Particulate Matter, SPM) mapping from MERIS imagery. Calibration of a Regional Algorithm for the Belgian Coastal Waters, MERIS User Workshop, 10-13th November 2003. European Space Agency, Frascati

Nixon, S.W., 1995. Coastal marine eutrophication: a definition, social causes, and future concerns. Ophelia, 41, 199-219.

OSPAR, 2003, Integrated Report 2003 on the Eutrophication Status of the OSPAR Maritime Area Based Upon the First Application of the Comprehensive Procedure, OSPAR Commission, Eutrophication Series, Publication nr. 189, ISBN 1-904426-25-5, download available at www.ospar.org.

OSPAR, 2008a, Nutrient reduction scenarios for the North Sea, OSPAR Commission, Eutrophication Series, Publication nr. 374, ISBN 978-1-906840-15-0, download available at www.ospar.org.

OSPAR 2008b. Second Integrated Report on the Eutrophication Status of the OSPAR Maritime Area. Eutrophication series N 372. ISBN 978-1-906840-13-6.

Pätsch, J., Radach, G., 1997. Long-term simulation of the eutrophication of the North Sea: temporal development of nutrients, chlorophyll and primary production in comparison to observations. Journal of Sea Research, 38, 275-310.

Pätsch, J., Lenhart, H.J., 2004. Daily Loads of Nutrients, Total Alkalinity, Dissolved Inorganic Carbon and Dissolved Organic Carbon of the European continental rivers for the years 19772002. Berichte aus dem Zentrum fur Meeres- und Klimaforschung; Reihe B: Oxeanographie. No 48, 159 pp.

Pätsch, J., W. Kühn, 2008, Nitrogen and carbon cycling in the North Sea and exchange with the North Atlantic - a model study. Part I. Nitrogen budget and fluxes, Cont. Shelf Res. 28, 767-787.

Peeters, J.C.H., Los, F.J., Jansen, R., Haas, H.A., Peperzak, L., De Vries, I., 1995. The oxygen dynamics of the Oyster Grounds, North Sea. Impact of Eutrofication and environmental conditions. Ophelia, 42, 257-288.

Philippart, C.J.M., Cadée G.C., van Raaphorst, W., Riegman R., 2000. Long-term phytoplankton-nutrient interactions in a shallow coastal sea: algal community structure, nutrient budgets, and denitrification potential. Limnol. Oceanogr. 45, 131-144.

Philippart, C.J.M., Beukema J.J., Cadée G.C., Dekker R., Goedhart, P.W., van Iperen J.M., Leopold. M.F, Herman P.M.J, 2007. Impacts of nutrient reduction on coastal communities. Ecosystems 10, 95-118.

Pohlmann, T., 1996. Predicting the thermocline in a circulation model of the North Sea. Part I: Model description, calibration, and verification. Continental Shelf Research 7, 131-146. 
Prandle, D., 1980. Co-tidal charts for the southern North Sea. Deutsche Hydrographische Zeitschrift 33, Heft 2, 68-81.

Proctor, R., James, I.D., 1996. A fine resolution 3-D model of the southern North Sea. Journal of Marine Systems 8, 285-294.

Proctor, R., Holt, J.T., Allen, I.,, Blackford, J., 2003. Nutrient fluxes and budgets for the North West European Shelf from a three-dimensional model. The Science of the Total Environment, 314-316, 7769-785.

Quisthoudt, C., 1987. Production primaire phytoplanctonique dans le d'etroit du Pas de Calais, France: variations spatiales et annuelles au large du Cap Gris-Nez. C.R. Acad. Sci., Paris 304, 3), 245-250.

Radach, G., Moll, A., 2006. Review of three-dimensional ecological modelling related to the North Sea shelf system - Part 2: Model validation and data needs. Oceanography and Marine Biology; an Annual Review, Vol. 44,1-60.

Rousseau, V., Breton, E., De Wachter, B., Beji, A., Deconinck, M., Huijgh, J., Bolsens, T., Leroy, D., Lancelot, C., 2004. IZEUT: Identification of Belgian maritime zones affected by eutrophication. Implementation of the OSPAR Common Procedure to combat eutrophication. Final report.

Siddorn, J.R., Holt, M.W., Osborne, J.P., Allen, J.I., Blackford, J.C., Gilbert, F.J., Holt, J.T., Proctor, R.; Mills, D.K.,, 2007. Modelling the hydrodynamics and ecosystem of the NorthWest European continental shelf for operational oceanography. Journal of Marine Systems, vol. 65, no. 1-4 SPEC. ISS., pp. 417-429, March 2007. doi: 10.1016/j.jmarsys.2006.01.018

Skogen, M.D., Mathisen, L.R. 2009. Long term effects of reduced nutrient inputs to the North Sea. Estuarine Coastal and Shelf Science, 82, 433-442. Available online: http://dx.doi.org/10.1016/j.ecss.2009.02.006.

Skogen, M. D., Moll, A., 2005. Importance of ocean circulation in ecological modeling: An example from the North Sea. Journal of Marine Systems. Vol. 57, no. 3-4, pp. 289-300.

Smetacek, V., Cloern J.E., 2008. On Phytoplankton Trends. Science, 319, 1346-1348.

Stips, A., Bolding, K., Pohlman, T., Burchard, H., 2004, Simulating the temporal and spatial dynamics of the North Sea using the new model getm, General Estuarine Transport Model), Ocean Dynamics, vol. 54, pp. 266—283, doi: 10.1007/s10236-003-0077-0

Tett, P., Gowen, R., Mills, D., Fernandes, T., Gilpin, L., Huxham, M., Kennington, K., Read, P., Service, M., Wilkinson, M., Malcolm, S., 2007. Defining and detecting undesirable disturbance in the context of marine eutrophication. Mar Poll Bull, 55, 282-297.

van der Molen, J., Bolding, K., Greenwood, N., Mills, D.K., 2009. A multiple grain-size model of suspended particulate matter in combined currents and waves in shelf seas. Journal of Geophysical Research, 114, doi:10.1029/2008JF001150.

Van Beusekom, J.E.E., Brockmann, U.H., Hesse, K.-J., Hickel, W., Poremba, K., Tillmann U., 1999. The importance of sediments in the transformation and turnover of nutrients and organic matter in the Wadden Sea and German Bight. German Journal Hydrography 51, 2/3), 245-266.

Vanhoutte-Brunier, A., Ménesguen A., Lefebvre A., Cugier P.,2009. Using a nitrogen-tracking technique in a 3D model of the primary production to assess the fueling sources of 
Phaeocystis globosa blooms in the eastern English Channel and the southern North Sea. Estuar. Coast. Shelf Sci., in revision.

Van Kessel, T., Winterwerp J.C., Van Prooijen, B.C., Van Ledden, M., Borst, W.G., 2009, Modelling the seasonal dynamics of SPM with a simple algorithm for the buffering of fines in a sandy seabed. Proceedings of INTERCOH'O7 Brest France. Special Issue Cont. Shelf Res. (to be published).

Van Raaphorst, W.; Malschaert H.; Van Haren H., 1998. Tidal resuspension and deposition of particulate matter in the Oyster Grounds, North Sea, Journal of Marine Research, 56, 257291.

Vichi, M., Ruardij, P., Baretta, J.W., 2004. "Link or sink: a modelling interpretation of the open Baltic biogeochemistry", Biogeosciences, Vol. 1, 1, pp 79-100, SRef-ID: 17264189/bg/2004-1-79.

Vichi, M., Masina, S., Navarra, A.., 2007. A generalized model of pelagic biogeochemistry for the global ocean ecosystem. Part II: Numerical simulations. Journal of Marine Systems, 64, 10-134. doi: 10.1016/j.jmarsys.2006.03.014

Villars, M.T., De Vries, I. (Eds), 1998. Report of the ASMO Modelling workshop on Eutrophication Issues, 5-8 Nov. 1996, The Hague, The Netherlands. Assessment and Monitoring, OSPAR Commission 1998.

Wakelin, S.L., Holt J.T., Proctor, R., 2009. The influence of initial conditions and open boundary conditions on shelf circulation in a 3D ocean-shelf model of the North East Atlantic. Ocean Dynamics 59, 67-81 doi:10.1007/s10236-008-0164-3.

Weston, K., Fernand, L., Nicholls, J., Marca-Bell, A., Mills, D., Sivyer D., Trimmer, M., 2008. Sedimentary and water column processes in the Oyster Ground: A potentially hypoxic region of the North Sea. Marine Environmental Research 65: 235-249. 
Tables

\begin{tabular}{|c|c|c|c|}
\hline Contracting Party & TOxN (\%) & $\mathrm{NH}_{4}(\%)$ & $\mathrm{PO}_{4}(\%)$ \\
\hline \multicolumn{4}{|c|}{ (a) Reductions achieved between 1985 and 2002} \\
\hline Netherlands & 0 & 70 & 70 \\
\hline Germany & 0 & 90 & 50 \\
\hline UK & 0 & 20 & 0 \\
\hline France & 0 & 10 & 60 \\
\hline \multicolumn{4}{|c|}{ (b) Scenario 1: Reductions of 2002 national loads necessary to achieve 50\% reduction compared to 1985} \\
\hline Netherlands & 50 & 0 & 0 \\
\hline Germany & 50 & 0 & 0 \\
\hline UK & 50 & 40 & 50 \\
\hline France & 50 & 40 & 0 \\
\hline \multicolumn{4}{|c|}{ (c) Scenario 2: Reductions of 2002 national loads necessary to achieve $70 \%$ reduction compared to 1985} \\
\hline Netherlands & 70 & 0 & 0 \\
\hline Germany & 70 & 0 & 40 \\
\hline UK & 70 & 60 & 70 \\
\hline France & 70 & 70 & 20 \\
\hline
\end{tabular}

Table 1: (a) The reductions in riverine nitrogen and phosphorus loads achieved by Contracting Parties by reducing riverine nutrient inputs in their waters in the period $1985-2002$. The additional \% reduction to be applied for the year 2002 to achieve the (a) $50 \%$ and (b) $70 \%$ reduction scenario for nitrogen and phosphorus in relation to 1985 . Note: where a $50 \%$ or $70 \%$ reduction in riverine nutrient loads compared to 1985 has already achieved, no further reduction is applied in relation to 2002. 


\begin{tabular}{|c|c|c|c|c|c|c|}
\hline $\begin{array}{l}\text { Model I } \\
\text { Forcing }\end{array}$ & $\begin{array}{l}\text { MIRO } \\
\& C O-3 D\end{array}$ & $\begin{array}{l}\text { ECO- } \\
\text { MARS3D }\end{array}$ & ECOHAM4 & $\begin{array}{l}\text { Delft3D- } \\
\text { GEM }\end{array}$ & GETM-BFM & $\begin{array}{l}\text { POLCOMS- } \\
\text { ERSEM }\end{array}$ \\
\hline $\begin{array}{l}\text { Workshop } \\
\text { Term }\end{array}$ & BE model & FR model & DE model & NL model & $\begin{array}{l}\text { UK-Cefas } \\
\text { model }\end{array}$ & $\begin{array}{l}\text { UK-POL } \\
\text { model }\end{array}$ \\
\hline Spin-up & $\begin{array}{l}2 \text { years } \\
(2002)\end{array}$ & $\begin{array}{lr}2 & \text { years } \\
(2000 & \text { and } \\
2001) & \end{array}$ & $\begin{array}{l}3 \text { years } \\
(2002)\end{array}$ & $\begin{array}{l}5 \quad \text { years } \\
(2002)\end{array}$ & $\begin{array}{l}8 \\
(2002)\end{array}$ & $\begin{array}{l}3 \text { years } \\
\text { (2001) and } 3 \\
\text { years (2002) }\end{array}$ \\
\hline $\begin{array}{l}\text { River } \\
\text { Loads }\end{array}$ & $\begin{array}{l}\text { ICG-EMO } \\
\text { Workshop } \\
\text { data } \quad+ \\
\text { small BE } \\
\text { rivers }\end{array}$ & 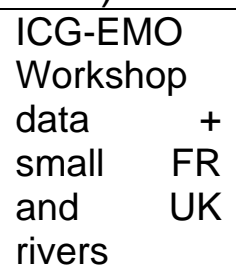 & $\begin{array}{l}\text { ICG-EMO } \\
\text { Workshop } \\
\text { data }\end{array}$ & $\begin{array}{l}\text { ICG-EMO } \\
\text { Workshop } \\
\text { data }\end{array}$ & $\begin{array}{l}\text { ICG-EMO } \\
\text { Workshop } \\
\text { data }\end{array}$ & $\begin{array}{l}\text { ICG-EMO } \\
\text { Workshop } \\
\text { data }\end{array}$ \\
\hline $\begin{array}{l}\text { Boundary } \\
\text { Condition }\end{array}$ & $\begin{array}{l}\text { POLCOMS- } \\
\text { ERSEM }\end{array}$ & $\begin{array}{l}\text { Ifremer's } \\
\text { MARS2D } \\
\text { model of N-W } \\
\text { European } \\
\text { Shelf: free- } \\
\text { surface } \\
\text { elevation and } \\
\text { currents. } \\
\text { ICES data : } \\
\text { monthly } \\
\text { climatologies } \\
\text { of nutrient } \\
\text { concentrations } \\
\text { salinity and } \\
\text { temperature. }\end{array}$ & $\begin{array}{l}\text { POLCOMS- } \\
\text { ERSEM }\end{array}$ & $\begin{array}{l}\text { POLCOMS- } \\
\text { ERSEM }\end{array}$ & $\begin{array}{l}\text { POLCOMS- } \\
\text { ERSEM } \\
\text { (T,S,nutrient } \\
\text { s) }\end{array}$ & $\begin{array}{l}\text { FOAM } \\
\text { (Forecast } \\
\text { Ocean } \\
\text { Assimilation } \\
\text { Model; } \\
\text { Bell et al., } \\
2000 \text { ) }\end{array}$ \\
\hline $\begin{array}{l}\text { Atmo- } \\
\text { spheric } \\
\text { nitrogen } \\
\text { deposition }\end{array}$ & None & None & \begin{tabular}{l}
\multicolumn{3}{l}{ EMEP 2002} \\
(incorrectly \\
used as \\
annual data \\
instead of \\
monthly)
\end{tabular} & $\begin{array}{l}\text { EMEP } 2002 \\
\text { (monthly) }\end{array}$ & None & EMEP 2002 \\
\hline $\begin{array}{l}\text { Meteoro- } \\
\text { logical } \\
\text { Forcing }\end{array}$ & $\begin{array}{l}\text { ECMWF } \\
\text { (winds, } \\
\text { pressure) } \\
\text { weekly } \\
\text { gridded } \\
\text { SST from } \\
\text { BSH } \\
\text { imposed at } \\
\text { surface }\end{array}$ & $\begin{array}{l}\text { Meteo-France } \\
\text { ARPEGE } \\
\text { model (6 hour } \\
\text { air temp., } \\
\text { moisture, } \\
\text { atmospheric } \\
\text { pressure and } \\
\text { wind.) } \\
\text { Cap de La } \\
\text { Hève } \\
\text { meteorological } \\
\text { station (daily } \\
\text { averaged } \\
\text { cloud cover.) } \\
\text { METEOSAT-7 } \\
\text { satellite solar } \\
\text { (hourly solar } \\
\text { irradiance) }\end{array}$ & NCEP & $\begin{array}{l}\text { ECMWF } \\
\text { (Wind } \\
\text { velocities, } \\
\text { Atmospheric } \\
\text { pressure) } \\
\text { KNMI } \\
\text { (Air } \\
\text { temperature, } \\
\text { relative } \\
\text { humidity and } \\
\text { cloud cover } \\
\text { time series } \\
\text { weather } \\
\text { station } \\
\text { Goeree; } \\
51^{\circ} 55.5 \quad \text { N, } \\
\text { 03 } 40.2 \text { E) } \\
\text { SST from } \\
\text { HD model } \\
\text { D3D Flow }\end{array}$ & $\begin{array}{l}\text { ECMWF } \\
\text { (Winds, } \\
\text { pressure, air } \\
\text { temperature, } \\
\text { relative } \\
\text { humidity, } \\
\text { cloud cover) }\end{array}$ & $\begin{array}{l}\text { ECMWF } \\
\text { (Winds, air } \\
\text { temperature, } \\
\text { relative } \\
\text { humidity, } \\
\text { cloud cover) }\end{array}$ \\
\hline
\end{tabular}

Table 2: Overview on the set-ups for all models that took part in the workshop. 


\section{Appendix A \\ Overview of models used in the reduction scenarios}

\begin{tabular}{|c|c|c|c|c|c|c|}
\hline Model name & MIRO\&CO-3D & ECO-MARS3D & ECOHAM4 & Delft3D-GEM & GETM-BFM & $\begin{array}{l}\text { POLCOMS- } \\
\text { ERSEM }\end{array}$ \\
\hline Workshop Term & BE model & FR model & DE model & NL model & UK-Cefas model & UK-POL model \\
\hline $\begin{array}{l}\text { Name } \\
\text { hydrodynamic } \\
\text { model }\end{array}$ & COHERENS & MARS-3D & HAMSOM & Delft3D & GETM & POLCOMS \\
\hline $\begin{array}{l}\text { Name } \\
\text { biogeochemical } \\
\text { model }\end{array}$ & MIRO & ECO-MARS-3D & ECOHAM4 & GEM & BFM & ERSEM \\
\hline Open source & $\begin{array}{l}\text { COHERENS: Yes } \\
\text { MIRO: No }\end{array}$ & No & Yes & No & $\begin{array}{l}\text { GETM: Yes } \\
\text { BFM: Yes }\end{array}$ & No \\
\hline $\begin{array}{l}\text { Horizontal } \\
\text { Resolution } \quad \Delta h \\
(\mathrm{~km})\end{array}$ & $\begin{array}{lr}5^{\prime} & \text { longitude } \\
(5.6 & \mathrm{km}) \quad \mathrm{x} \\
2.5^{\prime} & \text { latitude } \\
(4.6 \mathrm{~km}) & \end{array}$ & $4 \times 4 \mathrm{~km}$ & $20 \mathrm{~km}$ & $\begin{array}{ll}\text { Variable } & - \\
\text { curvilinear } & \text { grid } \\
\text { (min. } 1 \times 1 \quad \mathrm{~km} \text {, } \\
\operatorname{max.} 20 \times 20 \mathrm{~km} \text { ) }\end{array}$ & $\begin{array}{l}\text { approx. } 6 \text { nautical } \\
\text { miles }\end{array}$ & 12 \\
\hline $\begin{array}{l}\text { Vertical } \\
\text { resolution }\end{array}$ & 5 sigma layers & 12 sigma levels & 24 z-layers & 10 sigma layers & $\begin{array}{l}25 \text { layers, General } \\
\text { Coordinates }\end{array}$ & 32 s-levels \\
\hline $\begin{array}{l}\text { Longitude } \\
\text { (degree) }\end{array}$ & $4.0^{\circ} \mathrm{W}-5.0^{\circ} \mathrm{E}$ & $5.5^{\circ} \mathrm{W}-5.0^{\circ} \mathrm{E}$ & $15^{\circ} \mathrm{W}-14^{\circ} \mathrm{E}$ & $4^{\circ} \mathrm{W}-10^{\circ} \mathrm{E}$ & $5.15^{\circ} \mathrm{W}-18^{\circ} \mathrm{E}$ & $20^{\circ} \mathrm{W}-13^{\circ} \mathrm{E}$ \\
\hline $\begin{array}{l}\text { Latitude } \\
\text { (degree) }\end{array}$ & $48.5^{\circ} \mathrm{N}-52.5^{\circ} \mathrm{N}$ & $47.85^{\circ} \mathrm{N}-52.50^{\circ} \mathrm{N}$ & $47,5^{\circ} \mathrm{N}-64^{\circ} \mathrm{N}$ & $49^{\circ} \mathrm{N}-57^{\circ} \mathrm{N}$ & $48.5^{\circ} \mathrm{N}-60^{\circ} \mathrm{N}$ & $40^{\circ} \mathrm{N}-65^{\circ} \mathrm{N}$ \\
\hline $\begin{array}{l}\text { Time step } \Delta t \\
(\mathrm{sec})\end{array}$ & $900 \mathrm{sec}$ & variable $\sim 400 \mathrm{~s}$ & $60 \mathrm{~s}$ & $\begin{array}{l}\text { Transport timestep } \\
\text { (from D3D-FLOW) } \\
30 \text { min. Ecological } \\
\text { processes } \\
\text { timestep: } 24 \text { hrs }\end{array}$ & $\begin{array}{ll}45 & \text { sec } \\
\text { (stored daily) } & \end{array}$ & $\begin{array}{l}\text { 15s (barotropic), } \\
300 s \text { (baroclinic), } \\
\text { 1200s } \\
\text { (biochemical) }\end{array}$ \\
\hline $\begin{array}{l}\text { Oxygen } \\
\text { dynamics }\end{array}$ & No & Yes & Yes & Yes & Yes & Yes \\
\hline $\begin{array}{ll}\text { Temperature } & \& \\
\text { Salinity } & \\
\text { diagnostic } & \text { or } \\
\text { prognostic } & \\
\end{array}$ & $\begin{array}{l}\text { Weekly } 20 \mathrm{~km} \times 20 \\
\mathrm{~km} \text { gridded SST } \\
(\mathrm{BSH}) \text { imposed } \\
\text { salinity prognostic }\end{array}$ & $\mathrm{T}$ and S prognostic & $\begin{array}{l}\mathrm{T}: \quad \text { prognostic; } \\
\text { S: diagnostic }\end{array}$ & $\mathrm{T}$ and S prognostic & $\mathrm{T}$ and $\mathrm{S}$ prognostic & $\mathrm{T}$ and $\mathrm{S}$ prognostic \\
\hline SPM dynamics & $\begin{array}{l}\text { Seasonal TSM } \\
\text { from SeaWiFS } \\
\text { climatology (1997- } \\
2003) \text { imposed } \\
\text { at the surface / } \\
\text { bi-monthly }\end{array}$ & $\begin{array}{lr}\text { SiAM3D } & \text { model } \\
\text { and } & \text { satellite } \\
\text { forcing (SeaWiFS, } & \text { (SeaWrifh } \\
\text { monthly averages) }\end{array}$ & climatology & $\begin{array}{l}\text { Weekly varying, } \\
\text { based on monthly } \\
\text { SeaWiFS } \\
\text { composites }\end{array}$ & $\begin{array}{l}\text { local resuspension } \\
\text { by waves }\end{array}$ & IOP assimilation \\
\hline $\begin{array}{l}\text { Inclusion of } \\
\text { tides }\end{array}$ & Yes & Yes & No & Yes & Yes & Yes \\
\hline
\end{tabular}




\begin{tabular}{|c|c|c|c|c|c|c|}
\hline Model name & MIRO\&CO-3D & ECO-MARS3D & ECOHAM4 & Deft3D-GEM & GETM-BFM & $\begin{array}{l}\text { POLCOMS- } \\
\text { ERSEM }\end{array}$ \\
\hline Workshop Term & BE model & FR model & DE model & NL model & UK-Cefas model & UK-POL model \\
\hline \multicolumn{7}{|l|}{ Pelagic Part } \\
\hline $\begin{array}{l}\text { Pelagic matter } \\
\text { cycle }\end{array}$ & $\mathrm{C}, \mathrm{N}, \mathrm{P}, \mathrm{Si}$ & $\mathrm{N}, \mathrm{P}, \mathrm{Si}, \mathrm{O}$ & $\mathrm{C}, \mathrm{N}, \mathrm{P}, \mathrm{Si}, \mathrm{O}$ & $\begin{array}{l}\text { C organic part only, } \\
\mathrm{N}, \mathrm{P}, \mathrm{Si} \text { complete, } \\
\mathrm{O}\end{array}$ & $\mathrm{C}, \mathrm{N}, \mathrm{P}, \mathrm{Si}, \mathrm{O}$ & $\mathrm{C}, \mathrm{N}, \mathrm{P}, \mathrm{Si}, \mathrm{O}$ \\
\hline $\begin{array}{l}\text { No. of Pelagic } \\
\text { state variables }\end{array}$ & 32 & 19 & 24 & 23 & 45 & 51 \\
\hline $\begin{array}{l}\text { Pelagic } \\
\text { Nutrients (bulk } \\
\text { or explicit) }\end{array}$ & Explicit & Explicit & Explicit & Explicit & Explicit & Explicit \\
\hline $\begin{array}{l}\text { Types of } \\
\text { Phytoplankton }\end{array}$ & $\begin{array}{l}\text { Nanoflagellates } \\
\text { (3), diatoms (3), } \\
\text { Phaeocystis (4) }\end{array}$ & $\begin{array}{l}\text { Diatoms, } \\
\text { dinoflagellates, } \\
\text { small } \\
\text { phytoplankton, } \\
\text { Karenia mikimotoi, } \\
\text { Phaeocystis } \\
\text { globosa (4) }\end{array}$ & $\begin{array}{l}\text { Diatoms and } \\
\text { flagellates }\end{array}$ & $\begin{array}{l}12 \quad \text { Functional } \\
\text { groups: } \\
\text { diatoms } \\
\text { microflagellates (3), } \\
\text { dinoflagellates (3), } \\
\text { Phaeocystis (3) }\end{array}$ & $\begin{array}{l}\text { Diatoms, pico, } \\
\text { flagellates, } \\
\text { dinoflagellates }\end{array}$ & $\begin{array}{l}\text { Diatoms, pico, } \\
\text { flagellates, } \\
\text { dinoflagellates }\end{array}$ \\
\hline $\begin{array}{ll}\text { Types } & \text { of } \\
\text { Zooplankton }\end{array}$ & $\begin{array}{l}\text { Micro- and } \\
\text { mesozooplankton }\end{array}$ & $\begin{array}{l}\text { Micro- and } \\
\text { mesozooplankton }\end{array}$ & $\begin{array}{l}\text { Micro- and } \\
\text { mesozooplankton }\end{array}$ & 0 & $\begin{array}{l}\text { Micro- and } \\
\text { mesozooplankton } \\
\text { heterotrophic } \\
\text { nanoflagellates }\end{array}$ & $\begin{array}{l}\text { Micro- and } \\
\text { mesozooplankton } \\
\text { heterotrophic } \\
\text { nanoflagellates }\end{array}$ \\
\hline $\begin{array}{ll}\text { Types of } \\
\text { bacteria }\end{array}$ & $\begin{array}{l}\text { Heterotrophic } \\
\text { bacteria }\end{array}$ & None & $\begin{array}{l}\text { Heterotrophic } \\
\text { bacteria }\end{array}$ & None & $\begin{array}{l}\text { Heterotrophic } \\
\text { bacteria }\end{array}$ & $\begin{array}{l}\text { Heterotrophic } \\
\text { bacteria }\end{array}$ \\
\hline Pelagic POM & \begin{tabular}{l}
\multicolumn{3}{l}{ Particulate organic } \\
$\mathrm{C}, \mathrm{N} \& \mathrm{P}$ \\
of high \\
and low (1) \\
biodegradability, \\
Biogenic Silica
\end{tabular} & Yes & $\begin{array}{l}\text { Slow }(\mathrm{C}, \mathrm{N}, \mathrm{P}) \\
\text { and fast sinking } \\
\text { detritus }(\mathrm{C}, \mathrm{N}, \mathrm{P} \text {, } \\
\left.\mathrm{Si}, \mathrm{CaCO}_{3}\right)\end{array}$ & None & $\begin{array}{l}\text { Particulate } \\
\text { organic C, } \\
\mathrm{N} \& \mathrm{P} \text { of high } \\
\text { and low } \\
\text { biodegradability, } \\
\text { Biogenic Silica }\end{array}$ & Yes \\
\hline \multicolumn{7}{|l|}{ Benthic Part } \\
\hline $\begin{array}{l}\text { Benthic matter } \\
\text { cycle }\end{array}$ & $\mathrm{C}, \mathrm{N}, \mathrm{P}, \mathrm{Si}$ & $\mathrm{N}, \mathrm{P}, \mathrm{Si}, \mathrm{O}$ & $\begin{array}{l}\mathrm{C}, \quad \mathrm{N}, \quad \mathrm{P}, \quad \mathrm{Si}, \\
\mathrm{CaCO}_{3}\end{array}$ & $\mathrm{C}, \mathrm{N}, \mathrm{P}, \mathrm{Si}$ & $\mathrm{C}, \mathrm{N}, \mathrm{P}, \mathrm{Si}$ & $\mathrm{C}, \mathrm{N}, \mathrm{P}, \mathrm{Si}$ \\
\hline $\begin{array}{l}\text { No. of benthic } \\
\text { state variables }\end{array}$ & 6 & 10 & 5 & 4 & 53 (in 3 layers) & 44 \\
\hline $\begin{array}{l}\text { Benthic } \\
\text { Nutrients (bulk } \\
\text { or explicit) }\end{array}$ & $\begin{array}{l}\text { Diagenetic model } \\
\left(\mathrm{NO}_{3}, \mathrm{NH}_{4}, \mathrm{PO}_{4}\right) \\
\text { First-oder kinetics } \\
\text { dissolution for } \\
\text { biogenic } \mathrm{Si}\end{array}$ & Explicit & Bulk & Explicit & $\begin{array}{l}\text { Diagenetic model } \\
\left(\mathrm{NO}_{3}, \mathrm{NH}_{4}, \mathrm{PO}_{4}\right. \\
\left.\mathrm{SiO}_{2}\right)\end{array}$ & Explicit \\
\hline
\end{tabular}

\section{Figures}

Fig. 1:

Eutrophication status for 2002 according to OSPAR Comprehensive Procedure (OSPAR, 2003).

Fig. 2:

Overview on the six model domains of the ecosystem models that run the reduction scenarios.

Fig. 3:

Available annual river loads, aggregated by country, for a) $\mathrm{PO} 4$, b) $\mathrm{NH}_{4}$ and c) TOxN (NO3+NO2, low values for NL in mid 1990's are related to missing data).

Fig. 4:

Horizontal distribution of simulated net primary production (in $\mathrm{g} \mathrm{C} \mathrm{m}^{-2} \mathrm{yr}^{-1}$ ) for 2002 from the a) UK-POL, b) DE, c) UK-Cefas, d) NL, e) FR and f) BE model simulations.

\section{Fig. 5:}


Horizontal distribution of the percentage difference in net primary production obtained from the $50 \%$ reduction run compared to the standard run from the a) UK-POL, b) DE, c) UKCefas, d) NL, e) FR and f) BE model simulations.

\section{Fig. 6:}

Target areas for nutrient reduction scenarios and the position of Dutch measuring station Terschelling 135 (TERSLG135).

\section{Fig. 7:}

Mean winter concentrations of DIN and DIP at the surface and mean summer chlorophyll at the surface for the year 2002 (for the standard run and the $50 \%$ and $70 \%$ reduction scenarios for the target areas a) B-C1, b) F-C2, c) G-C1, d) NL-C2, e) NL-O2 and UK-C1.

\section{Fig. 8:}

Modelled winter DIN and DIP concentration from a long-term simulation with the NORWECOM model for the target areas a) G-C1 and b) N-C2.

\section{Fig. 9:}

Simulated time series of bottom oxygen concentration for a) the 2002 hindcast run and b) for the $50 \%$ reduction scenario at the position Terschelling $135 \mathrm{vs}$. OSPAR threshold of $6 \mathrm{mg}$ $\mathrm{O}_{2} / l$, derived from runs from the DE, the UK-Cefas and the NL model. For the hindcast runs the simulated time series are compared with the 2002 observations (crosses) and with the monthly averages (circle) over the period 1988-2003 with their corresponding standard deviations. 


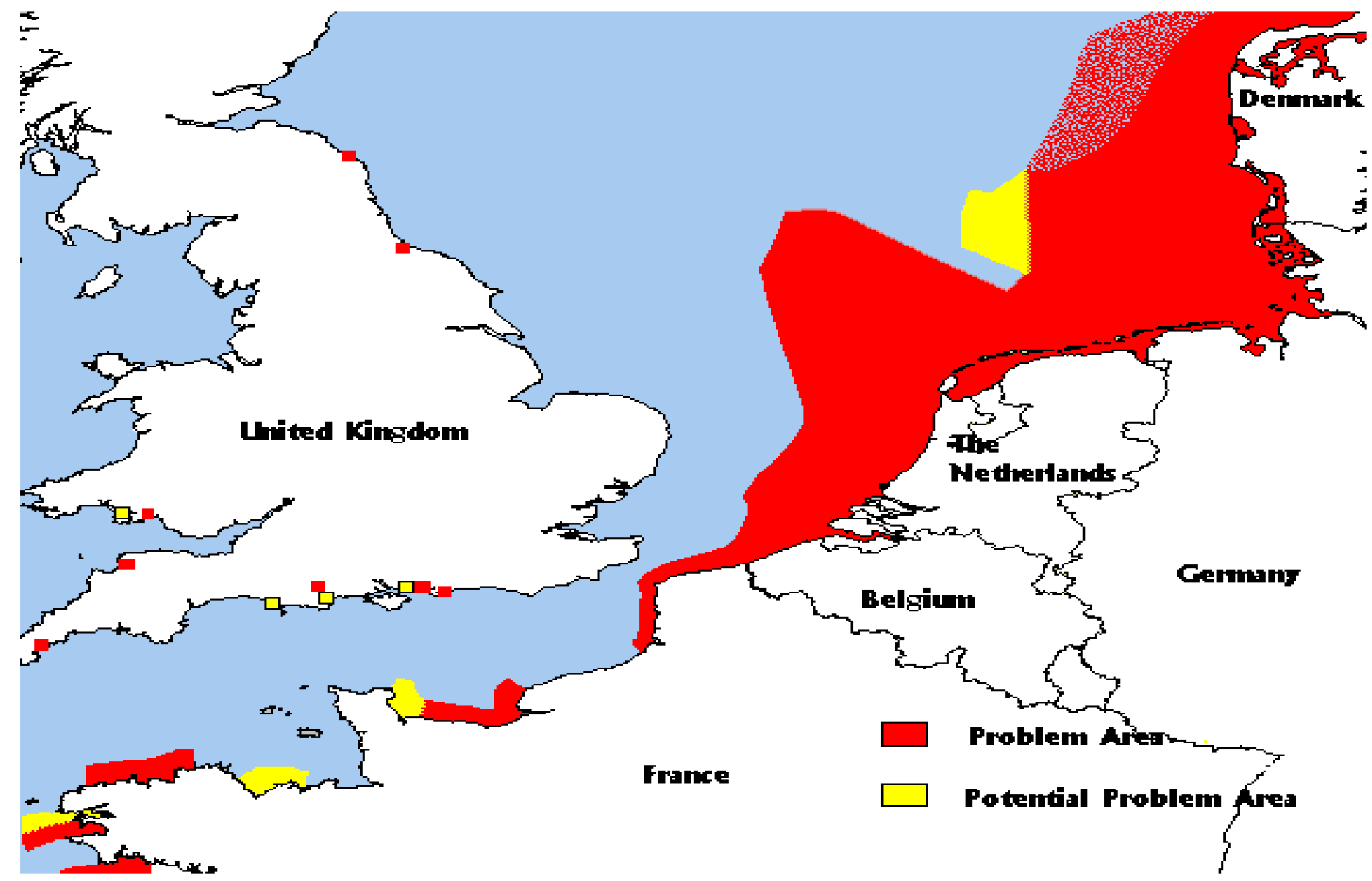

Fig. 1: 


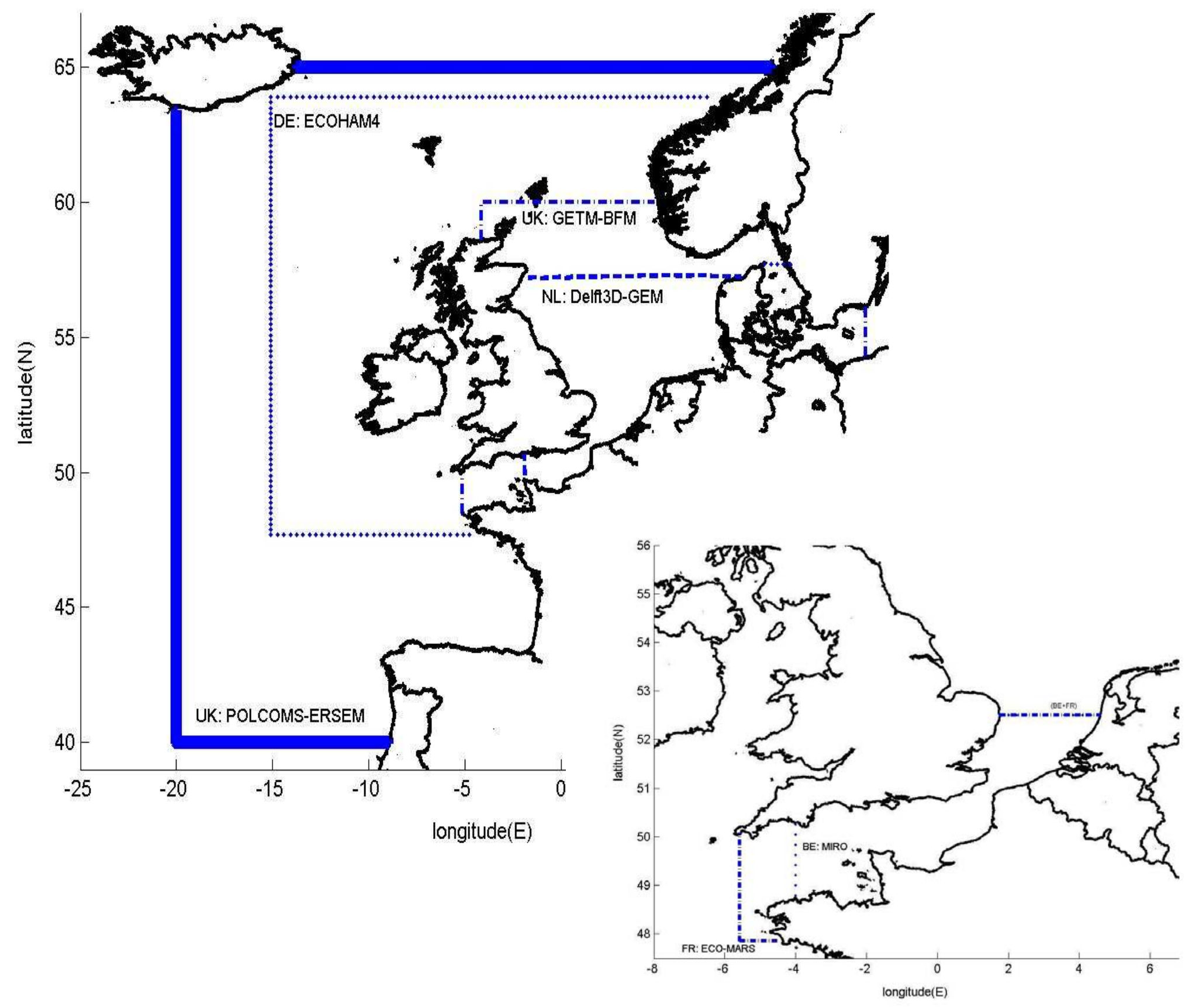

Fig. 2: 
a.)

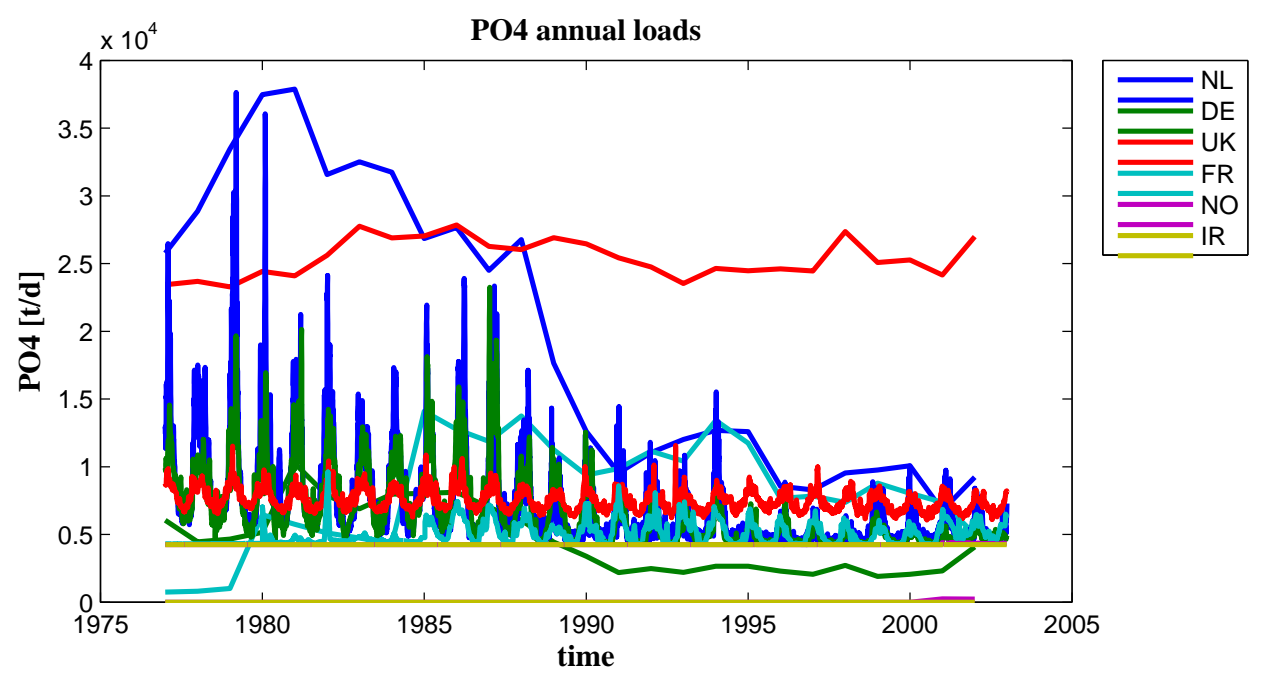

b.)

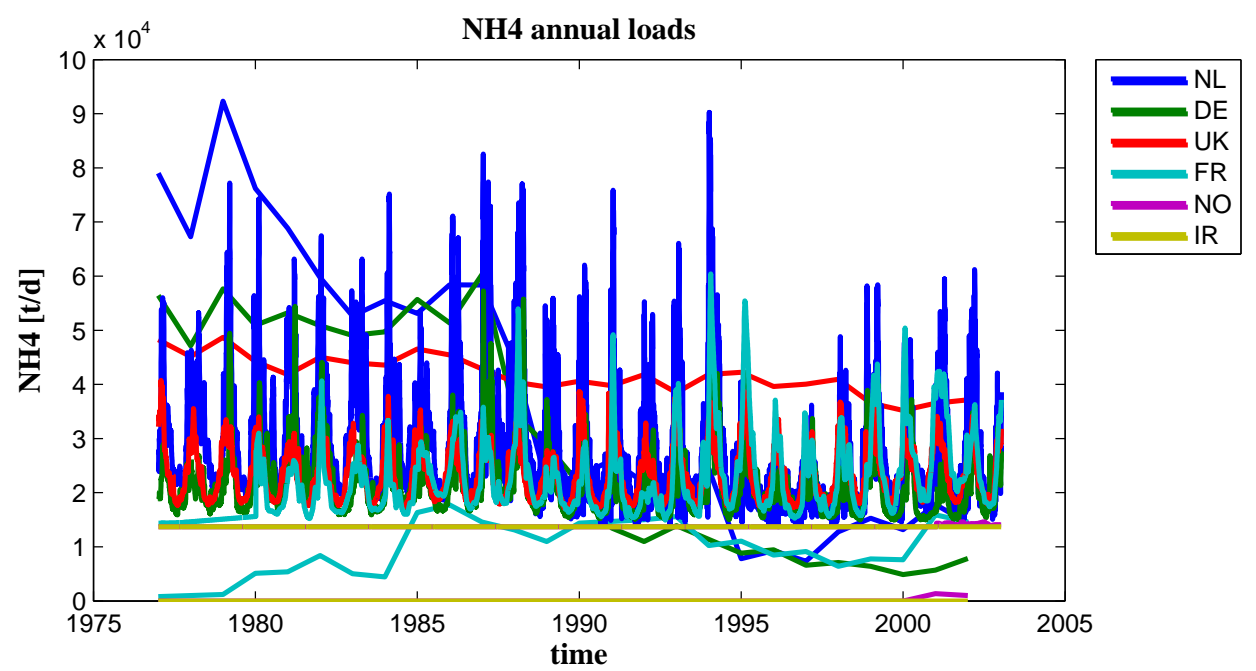

c.)

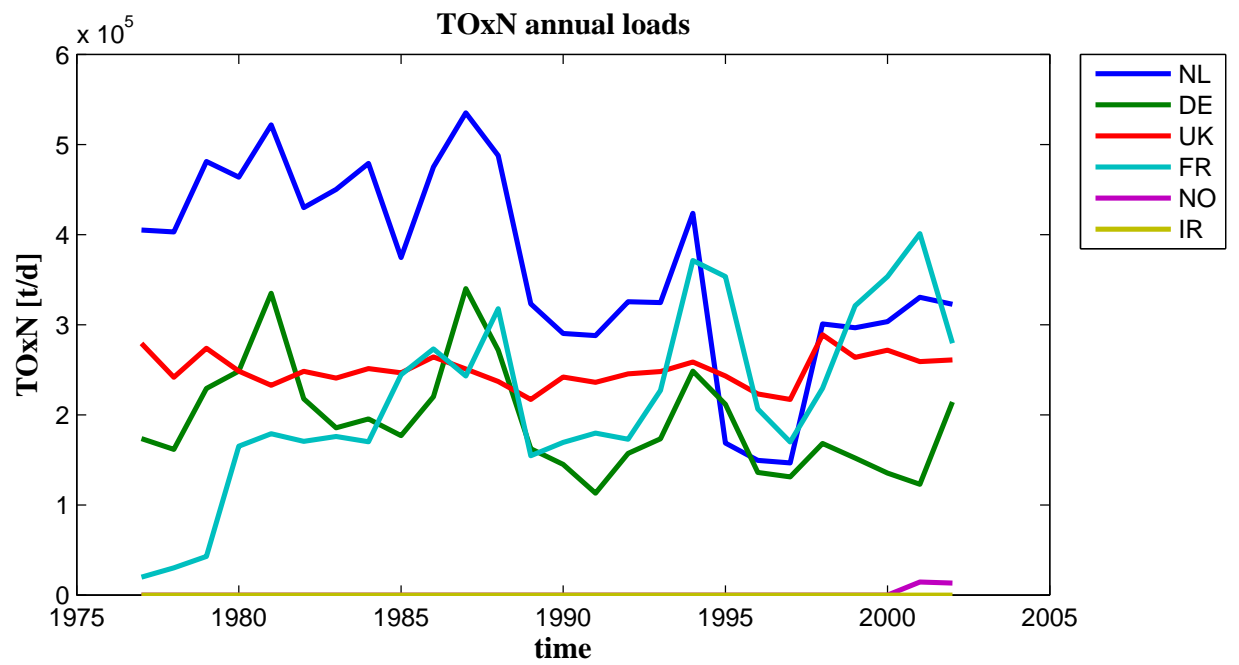

Fig. 3: 

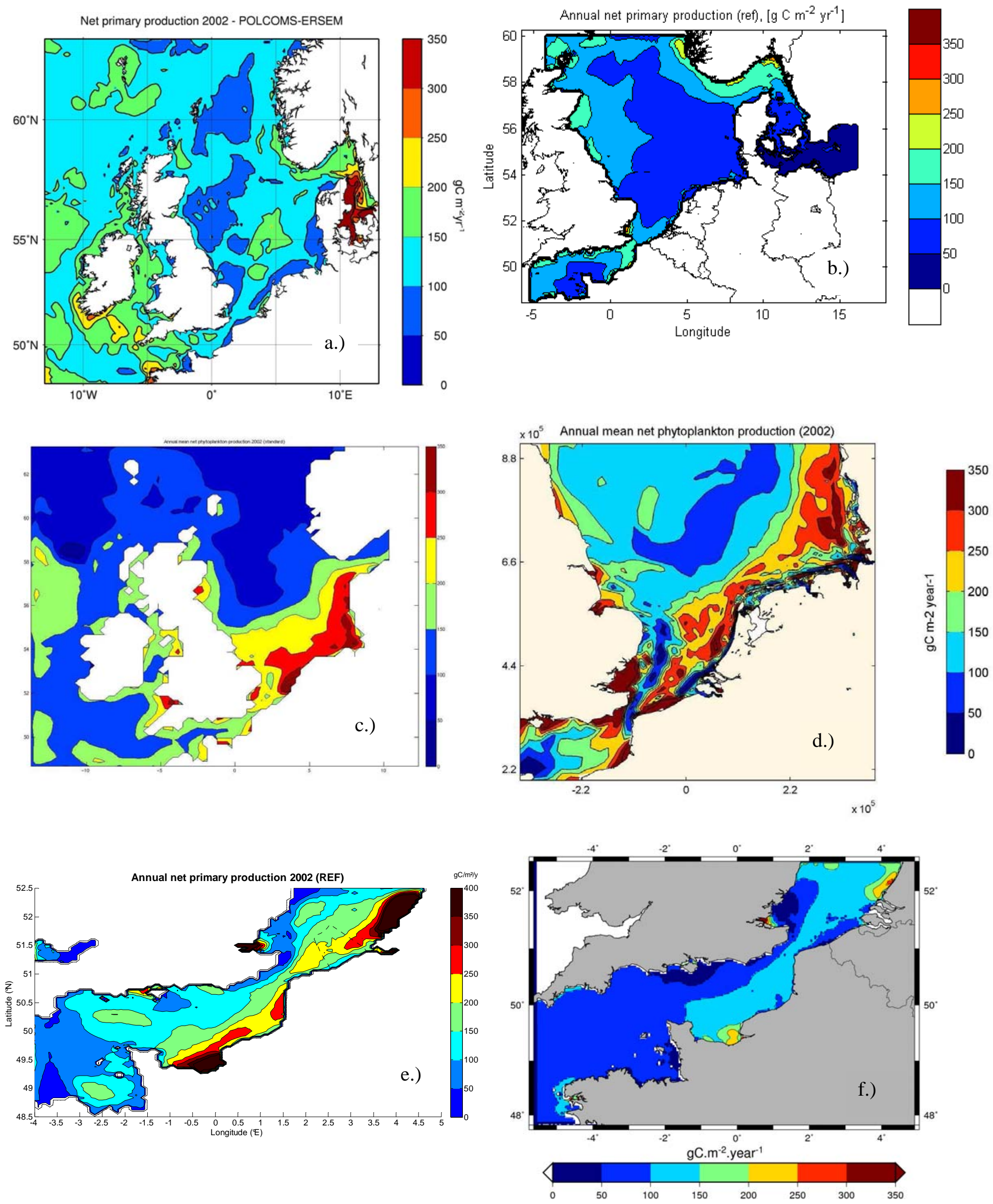

Fig. 4: 
Difference in net primary production 2002 (50\% - ref) - POLCOMS-ERSEM
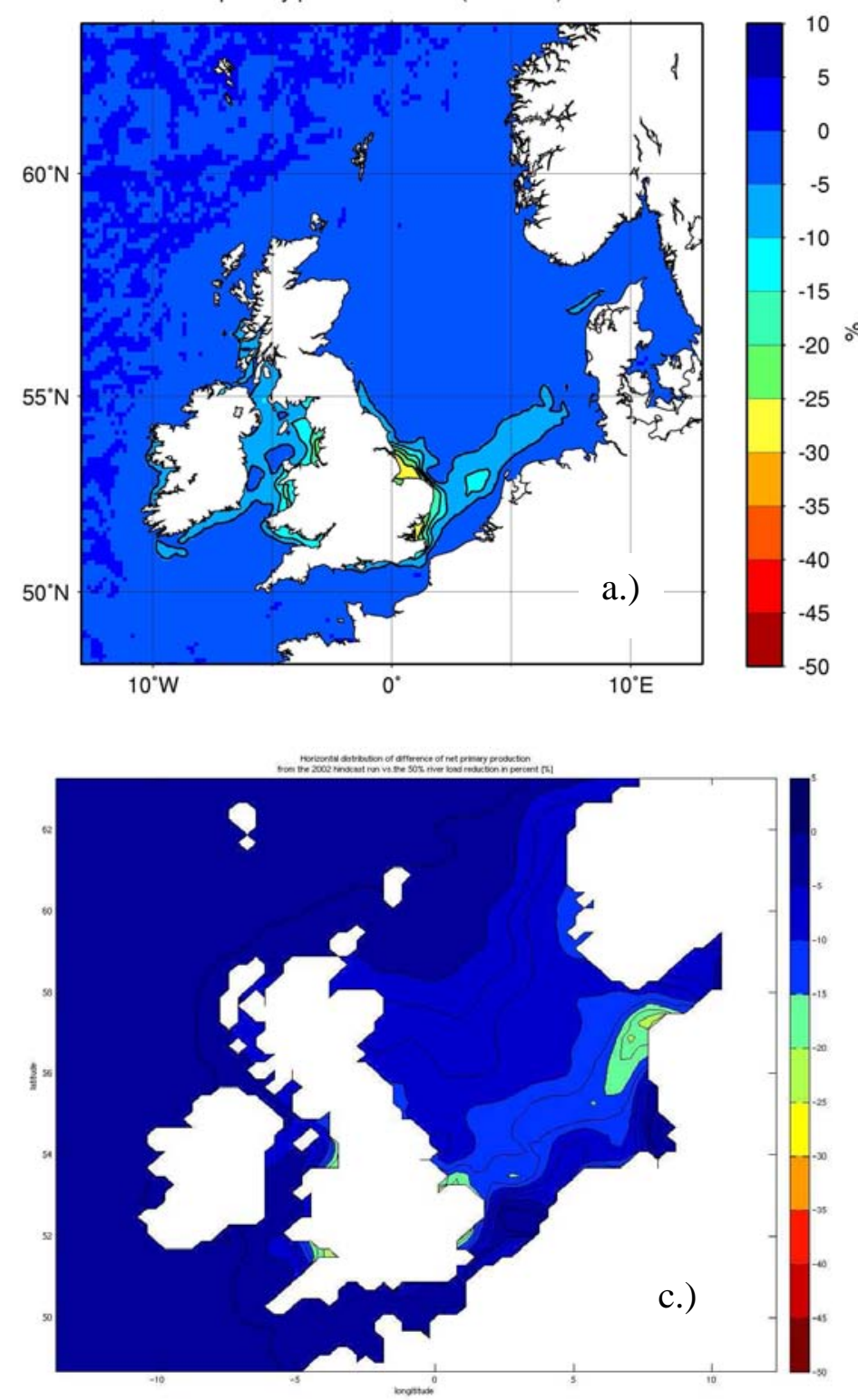

Reduction annual net primary production, [\%]
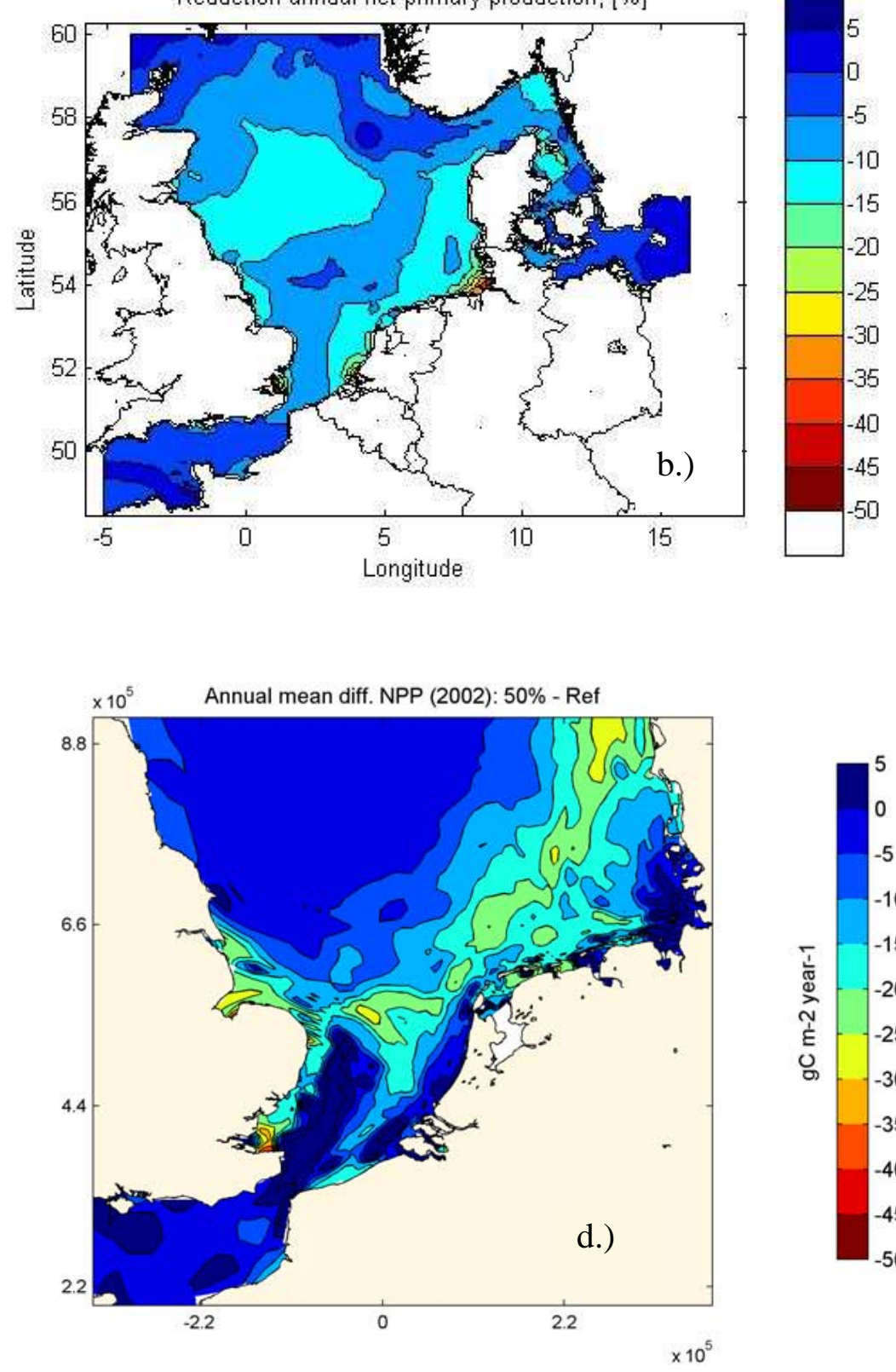

Annual difference NPP (2002) (50\%-REF)/REF

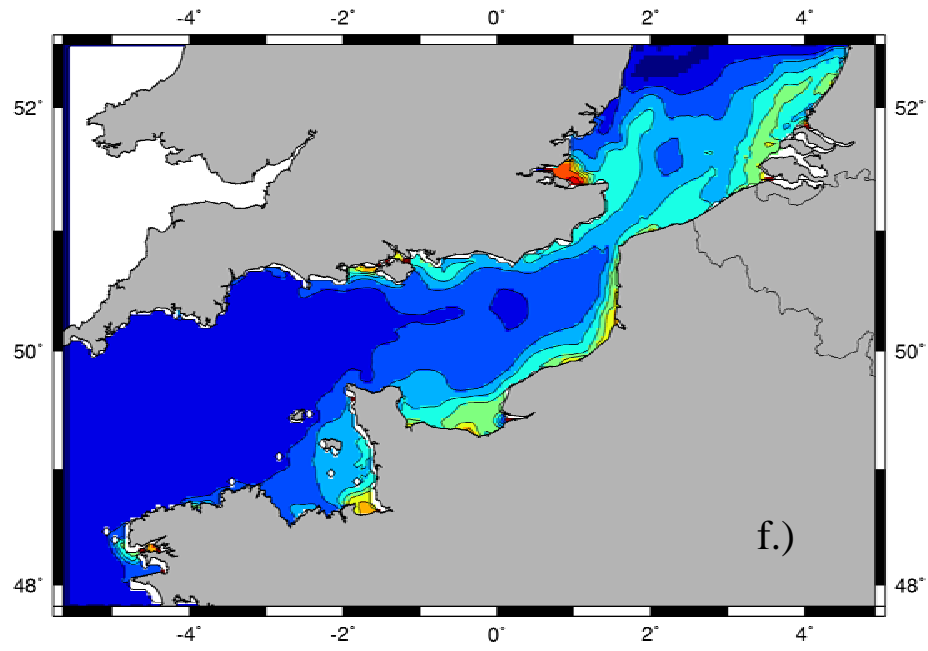

$\%$
Fig. 5:

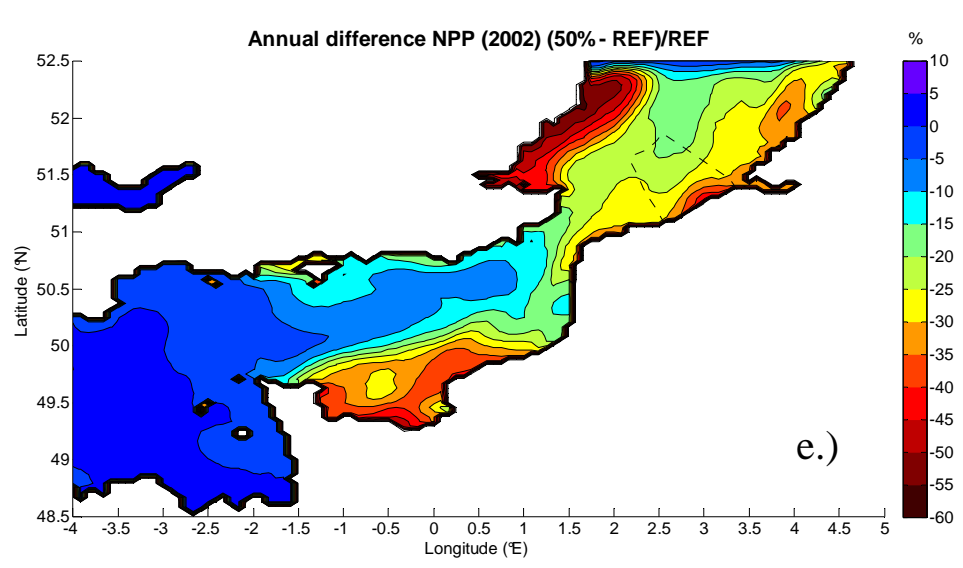




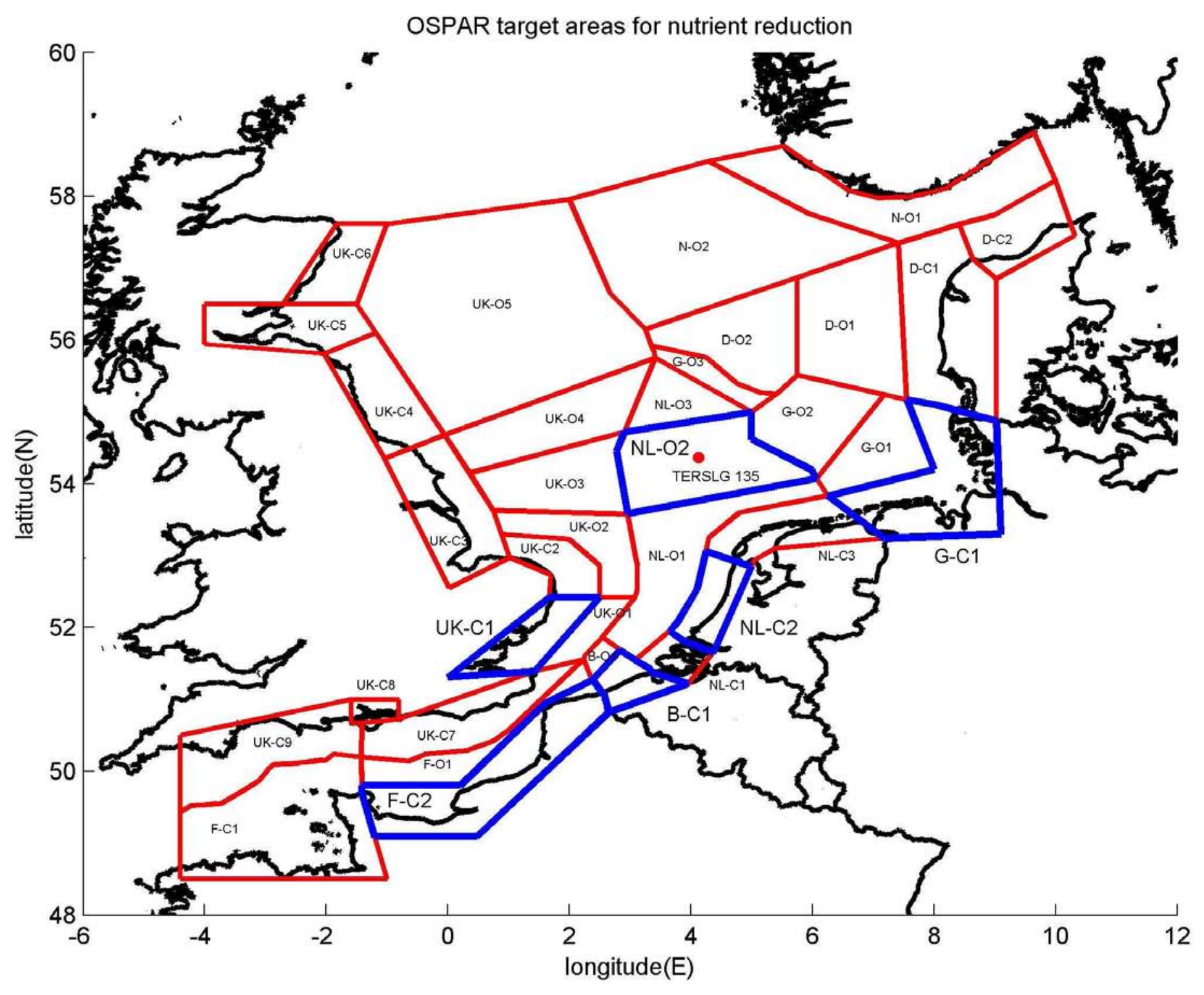

Fig. 6: 
a.)
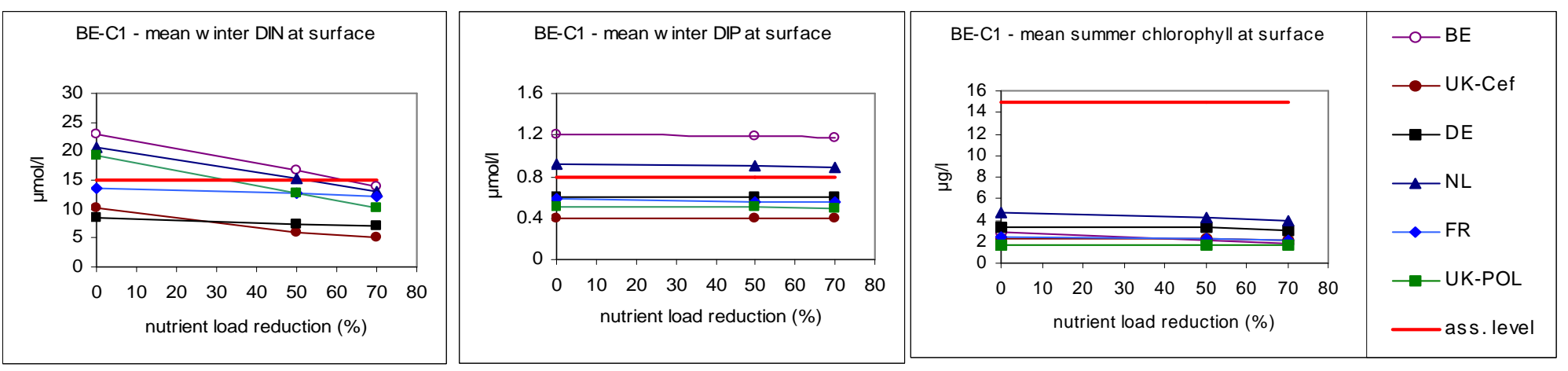

b.)
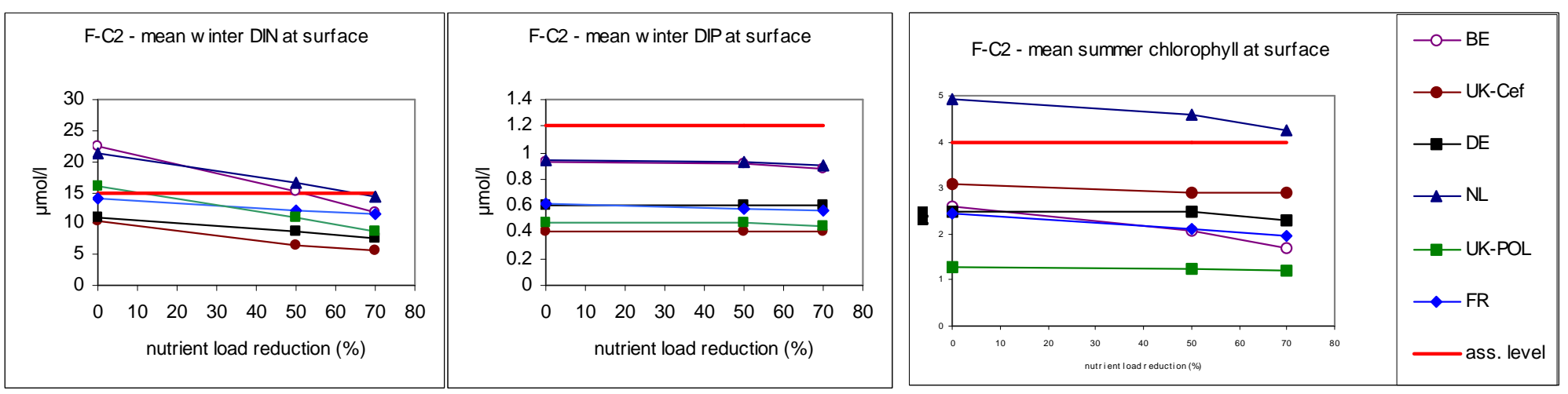

c.)
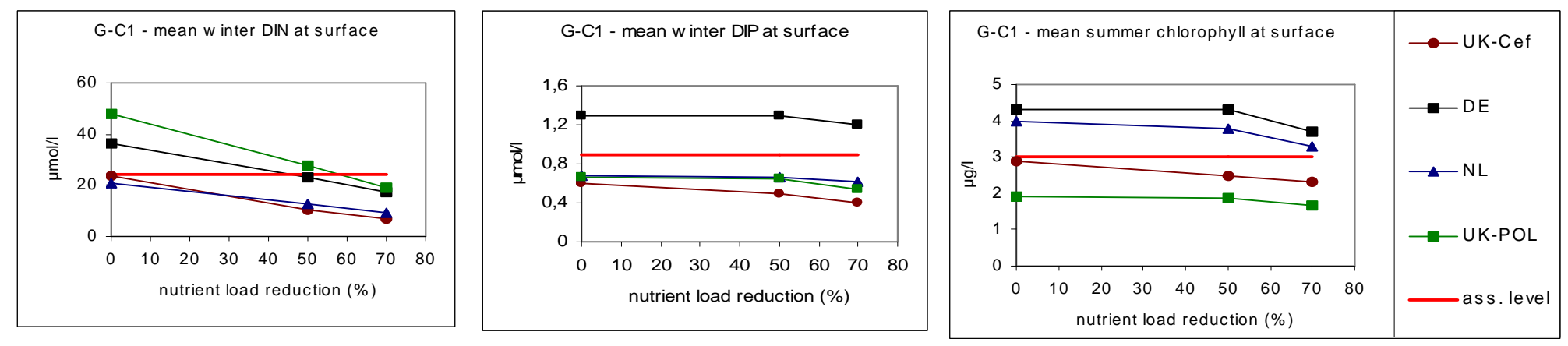

Fig. 7: 
d.)
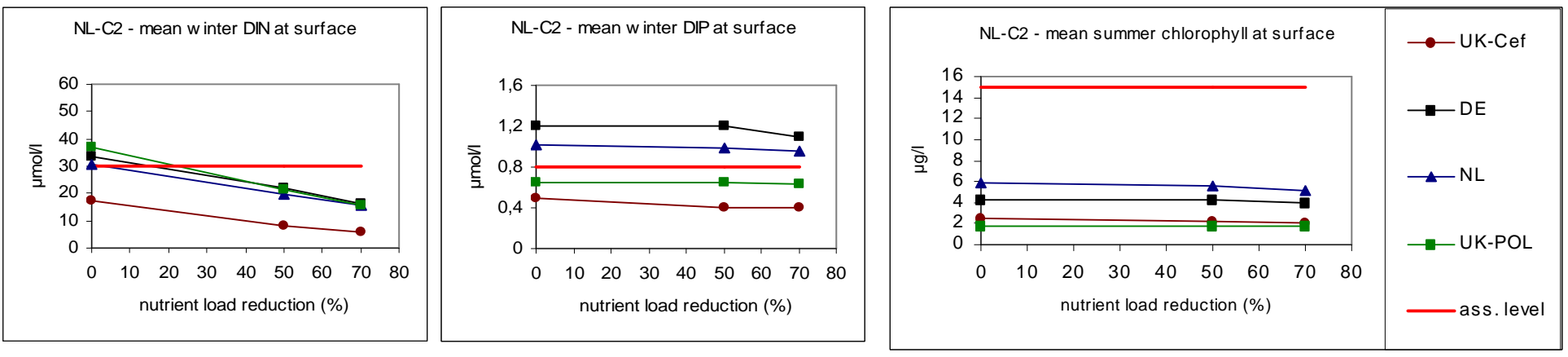

e.)
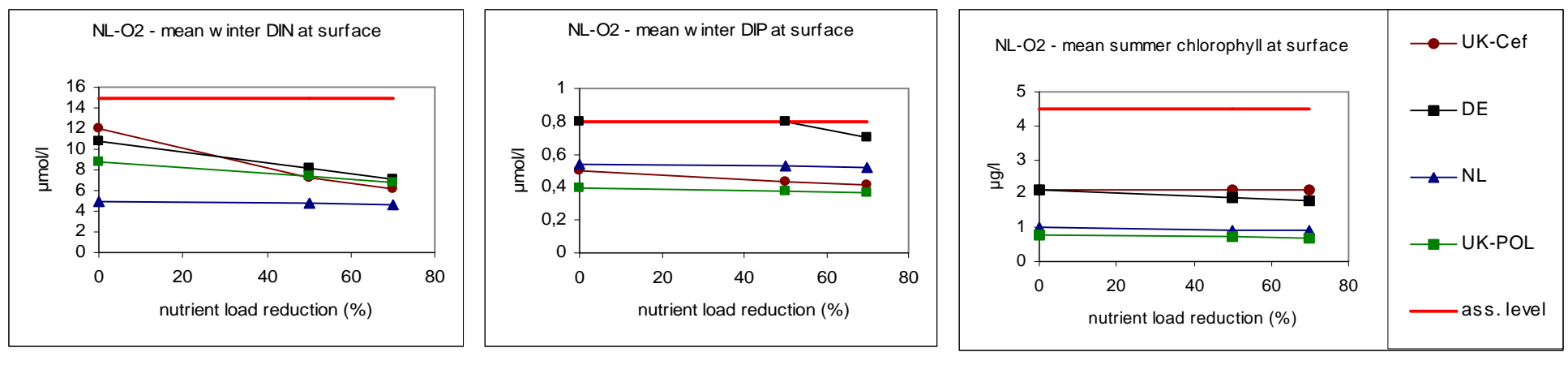

f.)
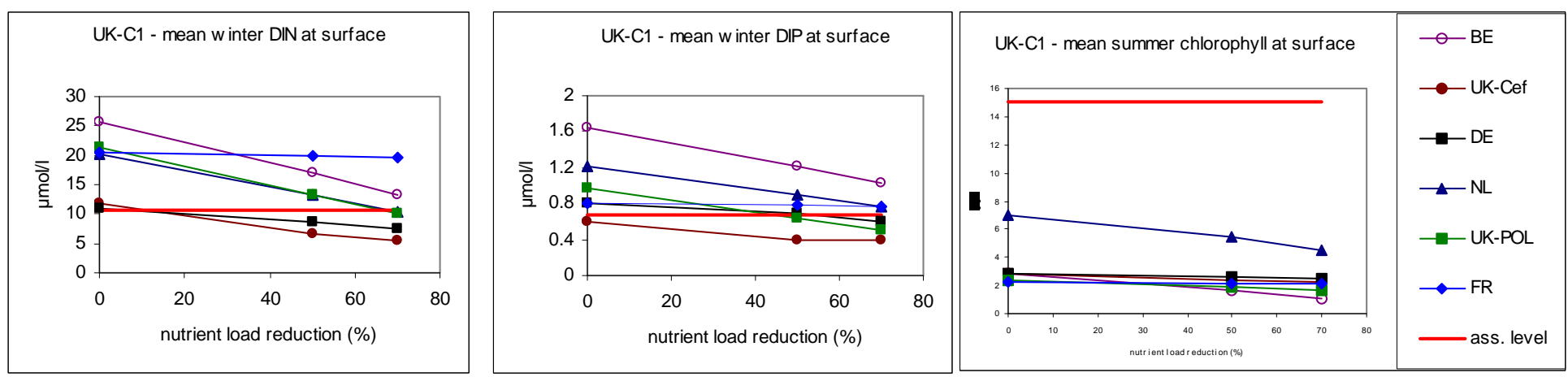

Fig. 7: 


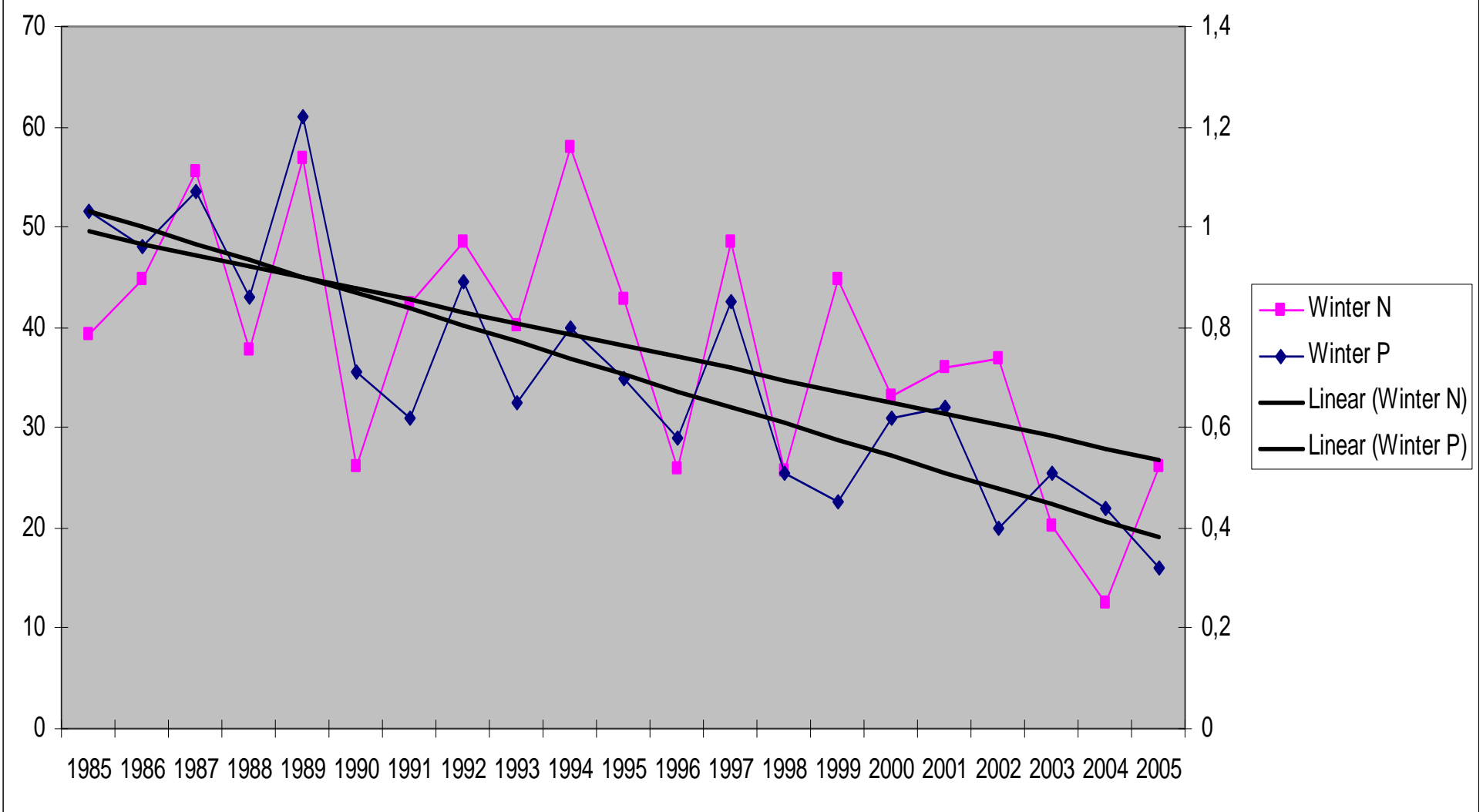

\section{German Coastal 1}

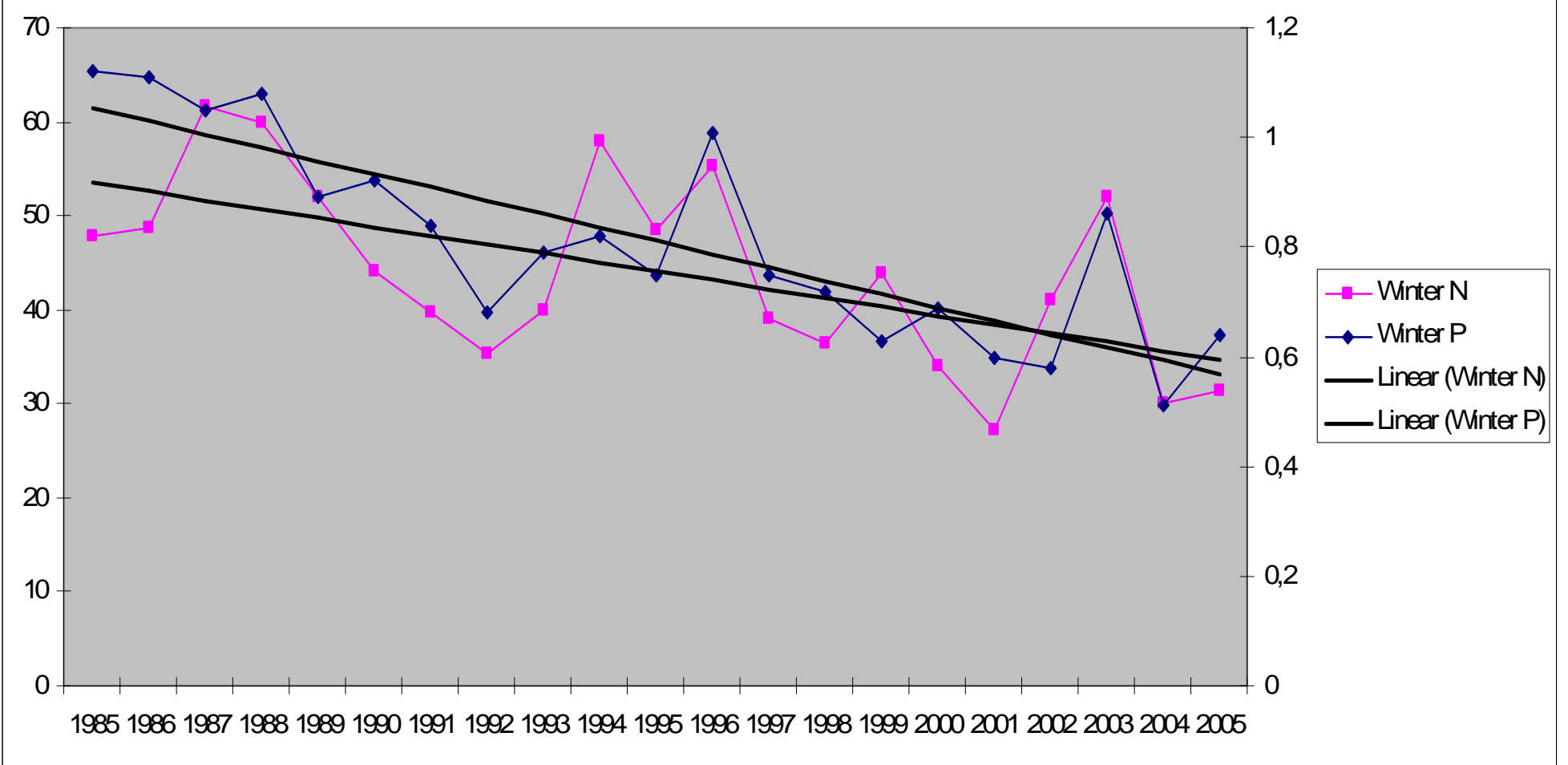

Fig. 8: 

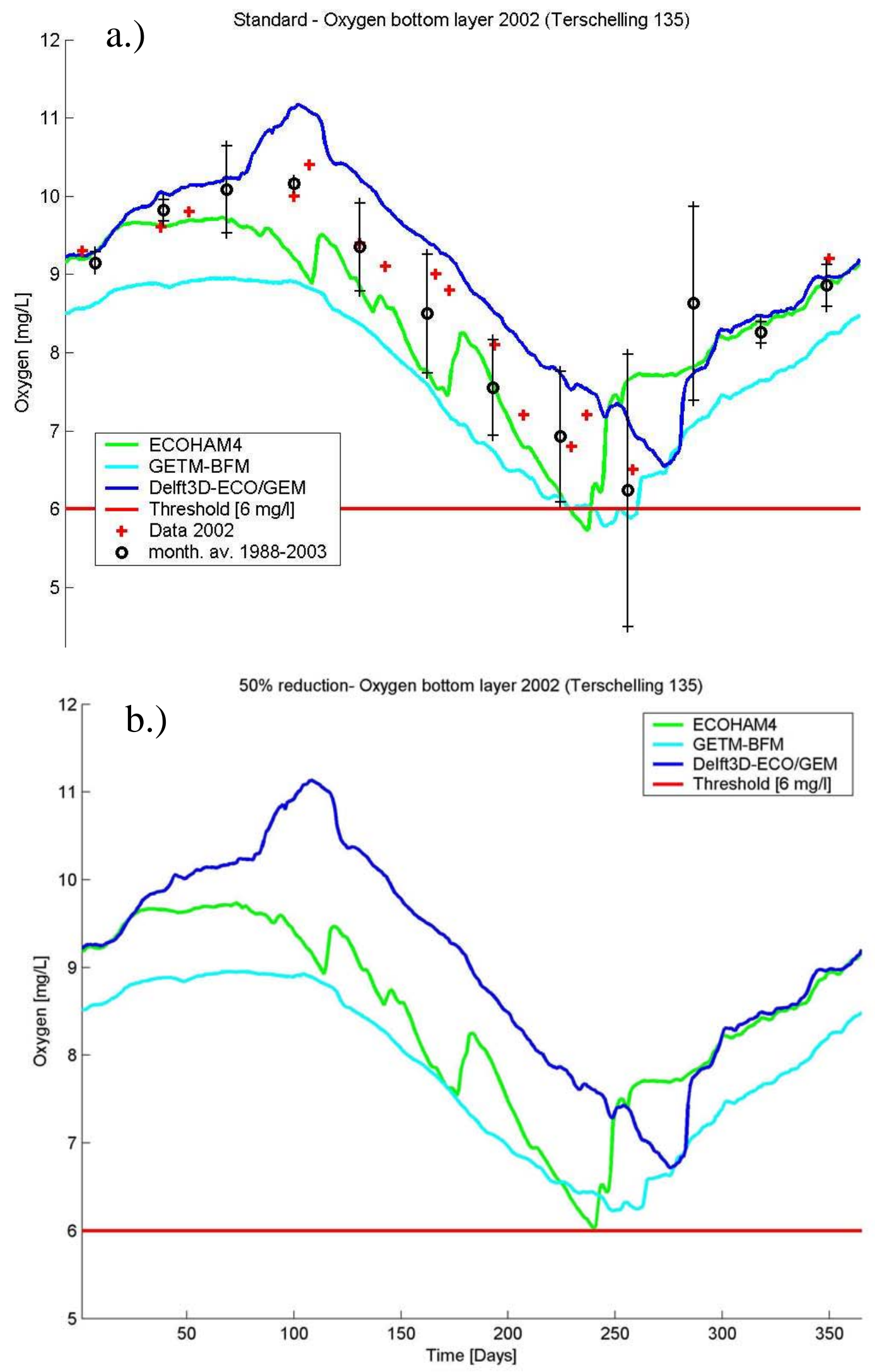

Fig. 9: 